\title{
Synthesis and Thermal, Photophysical, Electrochemical Properties of 3,3-di[3-Arylcarbazol-9-ylmethyl]oxetane Derivatives
}

\author{
Mateusz Korzec $^{1}{ }^{(\mathbb{D}}$, Daiva Tavgeniene ${ }^{2}$, Nizy Sara Samuel ${ }^{2}$ (D), Raminta Beresneviciute ${ }^{2}$, Gintare Krucaite ${ }^{2}$, \\ Agnieszka Katarzyna Pająk ${ }^{1}$ D , Sonia Kotowicz ${ }^{1}$ (D), Marharyta Vasylieva ${ }^{3}$ id, Paweł Gnida ${ }^{3}$ (D), \\ Jan Grzegorz Malecki ${ }^{1}\left(\mathbb{D}\right.$, Saulius Grigalevicius ${ }^{2, *(D)}$ and Ewa Schab-Balcerzak ${ }^{1,3, *(D)}$
}

1 Institute of Chemistry, University of Silesia, 9 Szkolna Str., 40-006 Katowice, Poland; mateusz.korzec@us.edu.pl (M.K.); agpajak@us.edu.pl (A.K.P.); sonia.kotowicz@us.edu.pl (S.K.); jan.malecki@us.edu.pl (J.G.M.)

2 Department of Polymer Chemistry and Technology, Kaunas University of Technology, Radvilenu Plentas 19, LT50254 Kaunas, Lithuania; daiva.tavgeniene@ktu.lt (D.T.); nizysamuel@gmail.com (N.S.S.); raminta.beresneviciute@ktu.lt (R.B.); gintare.krucaite@ktu.lt (G.K.)

3 Centre of Polymer and Carbon Materials, Polish Academy of Sciences, 34 M. Curie-Sklodowska Str., 41-819 Zabrze, Poland; mvasylieva@cmpw-pan.edu.pl (M.V.); pgnida@cmpw-pan.edu.pl (P.G.)

* Correspondence: saulius.grigalevicius@ktu.lt (S.G.); ewa.schab-balcerzak@us.edu.pl (E.S.-B.)

check for updates

Citation: Korzec, M.; Tavgeniene, D.; Samuel, N.S.; Beresneviciute, R.; Krucaite, G.; Pająk, A.K.; Kotowicz, S.; Vasylieva, M.; Gnida, P.; Malecki, J.G.; et al. Synthesis and Thermal,

Photophysical, Electrochemical Properties of 3,3-di[3-Arylcarbazol-9ylmethyl]oxetane Derivatives. Materials 2021, 14, 5569. https:// doi.org/10.3390/ma14195569

Academic Editors: Dominik Dorosz, Joanna Pisarska and Radosław Lisiecki

Received: 22 July 2021

Accepted: 22 September 2021

Published: 25 September 2021

Publisher's Note: MDPI stays neutral with regard to jurisdictional claims in published maps and institutional affiliations.

Copyright: (c) 2021 by the authors. Licensee MDPI, Basel, Switzerland. This article is an open access article distributed under the terms and conditions of the Creative Commons Attribution (CC BY) license (https:// creativecommons.org/licenses/by/ $4.0 /$ )
Abstract: Novel oxetane-functionalized derivatives were synthesized to find the impact of carbazole substituents, such as 1-naphtyl, 9-ethylcarbazole and 4-(diphenylamino)phenyl, on their thermal, photophysical and electrochemical properties. Additionally, to obtain the optimized ground-state geometry and distribution of the frontier molecular orbital energy levels, density functional theory (DFT) calculations were used. Thermal investigations showed that the obtained compounds are highly thermally stable up to $360^{\circ} \mathrm{C}$, as molecular glasses with glass transition temperatures in the range of $142-165^{\circ} \mathrm{C}$. UV-Vis and photoluminescence studies were performed in solvents of differing in polarity, in the solid state as a thin film on glass substrate, and in powders, and were supported by DFT calculations. They emitted radiation both in solution and in film with photoluminescence quantum yield from $4 \%$ to $87 \%$. Cyclic voltammetry measurements revealed that the materials undergo an oxidation process. Next, the synthesized molecules were tested as hole transporting materials (HTM) in perovskite solar cells with the structure $\mathrm{FTO} / \mathrm{b}-\mathrm{TiO}_{2} / \mathrm{m}-\mathrm{TiO}_{2} /$ perovskite/ $\mathrm{HTM} / \mathrm{Au}$, and photovoltaic parameters were compared with the reference device without the oxetane derivatives.

Keywords: oxetane derivatives; carbazole materials; hole transporting materials

\section{Introduction}

As a renewable energy source, solar energy is a very important way to solve environmental pollution and deficiency of current energy. Investigations into and development of efficient and cheap solar cells is a technological area where traditional silicon-based solar cells have been successfully commercialized regardless of some disadvantages. At this time, perovskite solar cells (PSCs) are regarded as one of the best alternatives to siliconbased photovoltaic (PV) devices. The intense heat required to purify silicon, the high amount of $\mathrm{CO}_{2}$ emitted during this process, as well as difficultly in deposition on flexible substrates can be listed as drawbacks of silicon PV. PSCs possess strong light absorption, high bipolar charge transporting possibility, long carrier diffusion length and lifetime as well as low exciton binding energy [1]. PSCs can be made with a low-temperature screen-printing process that is not only less energy-intensive but also less expensive. Moreover, it is believed that PSCs have lower carbon footprints and shorter energy payback periods than silicon [2]. Tremendous research efforts, which are devoted to the creation of high-power conversion efficiency PSCs, are highly related to the improved properties 
of newly developed hole transporting materials (HTM) [3]. Effective functions of the materials include extraction of photogenerated positive charges from a layer of perovskite, transportation of the charges to the metal electrode, and minimization of recombination losses at the $\mathrm{TiO}_{2}$ /perovskite/HTM interface [4,5]. Considering the literature review, it can be concluded that spiro-OMeTAD is the best-known HTM. It should be noted that it is an expensive material due to its complicated synthesis, mediocre hole carrier mobility and negative impact on stability which significantly increase the production cost of PV devices and their stability [6]. Due to these reasons the synthesis and investigation of novel efficient HTM is one of the hottest research topics in the PSCs field [7-10]. Among the reported HTM, carbazole-based compounds have drawn much attention due to good charge-transport ability of the carbazole units and low-cost of synthesis of the derivatives, which have provided a wide range of HTM by simple synthesis methods [11-13].

In this work, we describe synthesis and characterization of new simple carbazolebased oxetanes with 1-naphthyl, 9-ethylcarbazolyl and 4-(diphenylamino)phenyl moieties. The oxetanyl group containing molecules can form hydrogen bonds in solid state and the materials demonstrate high melting temperature $\left(\mathrm{T}_{\mathrm{m}}\right)$ or high glass transition temperature $\left(\mathrm{T}_{\mathrm{g}}\right)$ as well as formation of stable and homogeneous thin films due to intermolecular interactions, which can be promising for applications in organic optoelectronics including photovoltaics. They were tested as HTM in PSCs. The presented systematical studies are focused on finding the effect of some structural elements on crucial properties of the synthesized compounds. In design of new efficient HTMs, the role of systematical photophysical and optoelectronic investigations, which can help understand how to optimize the charge extraction and recombination processes by fine-tuning of the molecular structures, is essential to develop PV devices with improved performance. The obtained results should allow modeling of the chemical structure to obtain a material with specific characteristics for PV application. Some of the derivatives demonstrated improved amorphous film-forming properties, and, applied as HTM, lead to improvement of PV device parameters when compared with a reference cell without HTM.

\section{Experimental Methods}

\subsection{Materials}

9H-Carbazole (1), 3,3-bis(chloromethyl)oxetane, 4-(diphenylamino)phenylboronic acid, 9-ethyl-9H-carbazole-3-boronic acid pinacol ester, naphthalene-1-boronic acid, bis (triphenylphosphine)palladium(II) dichloride $\left(\mathrm{Pd}\left(\mathrm{PPh}_{3}\right)_{2} \mathrm{Cl}_{2}\right), \mathrm{K}_{2} \mathrm{CO}_{3}, \mathrm{KOH}, \mathrm{KI}, \mathrm{KIO}_{3}$, tetra-n-butylammonium hydrogen sulfate (TBAHS), $\mathrm{Na}_{2} \mathrm{SO}_{4}$ and solvents were purchased from Sigma Aldrich (Merck, Darmstadt, Germany) and used as received. Materials used for prepared perovskites solar cells: fluorine-doped tin oxide coated glass slides (FTOs, $7 \Omega$ /sq, Sigma-Aldrich), tetraethyl orthotitanate $\left(\left(\mathrm{C}_{2} \mathrm{H}_{5} \mathrm{O}\right)_{4} \mathrm{Ti}\right.$, Merck), hydrochloric acid ( $\mathrm{HCl}, \mathrm{CHEMPUR})$, anhydrous ethanol (EtOH, $\mathrm{POCH})$, paste Ti-Nanoxide T/SP (Solaronix), methylammonium iodide (MAI, Solaronix), isopropanol (IPA, POCH), chlorobenzene $\left(\mathrm{C}_{6} \mathrm{H}_{5} \mathrm{Cl}, \mathrm{POCH}\right)$. Lead iodide $\left(\mathrm{PbI}_{2}\right)$, anhydrous $\mathrm{N}, \mathrm{N}$-dimethylformamide (DMF), lithium bis(trifluoromethanesulfonyl)imide (Li-TFSI), 4-tert-butyl pyridine (TBP). All were purchased from Sigma-Aldrich. 3-Iodo-9H-carbazole (2) was synthesized according to the procedure described in the literature [14].

\subsection{Synthesis of Oxetane Derivatives}

3,3-Di[3-iodocarbazol-9-ylmethyl]oxetane (3) was synthesized and characterized according to the procedure described in the literature [15].

3,3-Di[3-(1-naphthyl)carbazol-9-ylmethyl]oxetane (4). $0.4 \mathrm{~g}(0.6 \mathrm{mmol})$ of 3,3-di[3iodocarbazol-9-yl]methyloxetane (3), $0.26 \mathrm{~g}(1.5 \mathrm{mmol})$ of naphthalene-1-boronic acid, $0.02 \mathrm{~g}(0.03 \mathrm{mmol})$ of $\mathrm{PdCl}_{2}\left(\mathrm{PPh}_{3}\right)_{2}$ and $0.17 \mathrm{~g}(3.0 \mathrm{mmol})$ of powdered $\mathrm{KOH}$ were stirred in $8 \mathrm{~mL}$ of THF containing degassed water $(1 \mathrm{~mL})$ at $80^{\circ} \mathrm{C}$ under nitrogen for $1.5 \mathrm{~h}$. After TLC control the reaction mixture was cooled and quenched by the addition of ice water. The product was extracted with chloroform. The combined extract was dried over anhydrous 
$\mathrm{Na}_{2} \mathrm{SO}_{4}$. The crude product was purified by silica gel column chromatography using the mixture of ethyl acetate and hexane (vol. ratio 1:7) as an eluent. Yield: $0.3 \mathrm{~g}$ of white crystals $(75 \%)$. DSC: $\mathrm{T}_{\mathrm{m}}=250{ }^{\circ} \mathrm{C}$. MS $\left(\mathrm{APCI}^{+}, 20 \mathrm{~V}\right): 669.49([\mathrm{M}+\mathrm{H}], 100 \%) .{ }^{1} \mathrm{H} \mathrm{NMR}$ (400 MHz, $\left.\mathrm{CDCl}_{3}, \delta: \mathrm{ppm}\right): 8.21-8.04(\mathrm{~m}, 4 \mathrm{H}, \mathrm{Ar}), 7.93-7.79(\mathrm{~m}, 6 \mathrm{H}, \mathrm{Ar}), 7.56-7.28(\mathrm{~m}$, $16 \mathrm{H}, \mathrm{Ar}), 7.26-7.20(\mathrm{~m}, 2 \mathrm{H}, \mathrm{Ar}), 4.75\left(\mathrm{~s}, 4 \mathrm{H}, 2 \times \mathrm{OCH}_{2}\right), 4.72\left(\mathrm{~s}, 4 \mathrm{H}, 2 \times \mathrm{NCH}_{2}\right) .{ }^{13} \mathrm{C} \mathrm{NMR}$ (100 MHz, $\left.\mathrm{CDCl}_{3}, \delta: \mathrm{ppm}\right): 141.90,140.85,140.65,133.90,132.52,132.15,128.38,128.30$, $127.41,126.38,126.28,126.04,125.76,125.45,123.46,123.41,122.09,120.79,119.98,108.876$, 108.44, 76.12, 50.79, 47.64. FT-IR (KBr), cm ${ }^{-1}:$ 3051, 2954, 2923, 2853, 1941, 1733, 1623, 1600, 1572, 1535, 1490, 1465, 1394, 1330, 1290, 1264, 1226, 1156, 986, 968, 800, 776, 745.

3,3-Di[3-(9-ethylcarbazol-3-yl)carbazol-9-ylmethyl]oxetane (5). $0.4 \mathrm{~g}(0.6 \mathrm{mmol})$ of 3,3-di[3-iodocarbazol-9-yl]methyloxetane (3), $0.48 \mathrm{~g}(1.5 \mathrm{mmol})$ of 9-ethyl-9H-carbazole3-boronic acid pinacol ester, $0.02 \mathrm{~g}(0.03 \mathrm{mmol})$ of $\mathrm{PdCl}_{2}\left(\mathrm{PPh}_{3}\right)_{2}$ and $0.17 \mathrm{~g}(3.0 \mathrm{mmol})$ of powdered $\mathrm{KOH}$ were stirred in $8 \mathrm{~mL}$ of THF containing degassed water $(1 \mathrm{~mL})$ at $80^{\circ} \mathrm{C}$ under nitrogen for $2 \mathrm{~h}$. After TLC control the reaction mixture was cooled and quenched by the addition of ice water. The product was extracted with chloroform. The combined extract was dried over anhydrous $\mathrm{Na}_{2} \mathrm{SO}_{4}$. The crude product was purified by silica gel column chromatography using the mixture of ethyl acetate and hexane (vol. ratio 1:5) as an eluent. Yield: $0.25 \mathrm{~g}$ of white amorphous product (52\%). $\mathrm{MS}\left(\mathrm{APCI}^{+}, 20 \mathrm{~V}\right): 803.58$ ([M+H], 100\%). ${ }^{1} \mathrm{H}$ NMR (400 MHz, $\left.\mathrm{CDCl}_{3}, \delta: \mathrm{ppm}\right): 8.31-8.09$ (m, 6H, Ar), 7.47-7.34 (m, $10 \mathrm{H}, \mathrm{Ar}), 7.31-7.12(\mathrm{~m}, 10 \mathrm{H}, \mathrm{Ar}), 4.65\left(\mathrm{~s}, 4 \mathrm{H}, 2 \times \mathrm{OCH}_{2}\right), 4.64\left(\mathrm{~s}, 4 \mathrm{H}, 2 \times \mathrm{NCH}_{2}\right), 4.37-4.26(\mathrm{~m}$, $\left.4 \mathrm{H}, 2 \times \mathrm{NCH}_{2} \mathrm{CH}_{3}\right), 1.38\left(\mathrm{t}, 6 \mathrm{H}, J=6.8 \mathrm{~Hz}, 2 \times \mathrm{CH}_{3}\right) .{ }^{13} \mathrm{C} \mathrm{NMR}\left(100 \mathrm{MHz}, \mathrm{CDCl}_{3}, \delta: \mathrm{ppm}\right):$ $141.90,140.50,140.44,139.16,134.44,132.97,126.24,126.04,125.78,125.53,123.95,123.59$, $123.57,123.15,120.77,120.57,119.80,119.20,119.09,118.87,108.99,108.86,108.73,108.60$, 76.07, 50.825, 47.52, 37.68, 13.90. FT-IR (KBr), cm ${ }^{-1}: 3048,2967,2928,2870,1877,1731,1627$, 1600, 1472, 1456, 1380, 1330, 1231, 1154, 1124, 1088, 1065, 1024, 969, 878, 798, 781, 745, 727.

3,3-Di[3-(4-(diphenylamino)phenyl)carbazol-9-ylmethyl]oxetane (6). $0.4 \mathrm{~g}(0.6 \mathrm{mmol})$ of 3,3-di[3-iodocarbazol-9-yl]methyloxetane (3), $0.43 \mathrm{~g}$ (1.5 mmol) of 4-(diphenylamino) phenylboronic acid, $0.02 \mathrm{~g}(0.03 \mathrm{mmol})$ of $\mathrm{PdCl}_{2}\left(\mathrm{PPh}_{3}\right)_{2}$ and $0.17 \mathrm{~g}(3.0 \mathrm{mmol})$ of powdered $\mathrm{KOH}$ were stirred in $8 \mathrm{~mL}$ of THF containing degassed water $(1 \mathrm{~mL})$ at $80^{\circ} \mathrm{C}$ under nitrogen for $1.5 \mathrm{~h}$. After TLC control the reaction mixture was cooled and quenched by the addition of ice water. The product was extracted with chloroform. The combined extract was dried over anhydrous $\mathrm{Na}_{2} \mathrm{SO}_{4}$. The crude product was purified by silica gel column chromatography using the mixture of ethyl acetate and hexane (vol. ratio 1:7) as an eluent. Yield: $0.3 \mathrm{~g}$ of white amorphous product (56\%). MS (APCI $\left.{ }^{+}, 20 \mathrm{~V}\right): 903.56([\mathrm{M}+\mathrm{H}], 100 \%)$. ${ }^{1} \mathrm{H}$ NMR (400 MHz, CDCl 3 , 8:ppm): 8.24-8.06 (m, 6H, Ar), 7.63-7.55 (m, 2H, Ar), 7.51-7.33 $(\mathrm{m}, 7 \mathrm{H}, \mathrm{Ar}), 7.29-7.19(\mathrm{~m}, 12 \mathrm{H}, \mathrm{Ar}), 7.14-7.03(\mathrm{~m}, 12 \mathrm{H}, \mathrm{Ar}), 6.99-6.90(\mathrm{~m}, 5 \mathrm{H}, \mathrm{Ar}), 4.65(\mathrm{~s}$, $\left.4 \mathrm{H}, 2 \times \mathrm{OCH}_{2}\right), 4.61\left(\mathrm{~s}, 4 \mathrm{H}, 2 \times \mathrm{NCH}_{2}\right) .{ }^{13} \mathrm{C} \mathrm{NMR}\left(100 \mathrm{MHz}, \mathrm{CDCl}_{3}, 8: \mathrm{ppm}\right): 147.82,146.65$, $141.86,140.66,135.95,132.89,129.30,127.95,126.32,125.33,124.41,124.28,123.87,123.48$, $122.807,120.71,119.90,118.66,108.96,108.85,75.99,50.77,47.49$. FT-IR (KBr), $\mathrm{cm}^{-1}: 3055$, 3031, 2954, 2923, 2866, 1965, 1625, 1589, 1515, 1488, 1451, 1384, 1331, 1275, 1230, 1178, 1155, $1073,1028,969,889,803,748,696$.

\subsection{Instrumentation and Characterization Methods}

Instrumentation, characterization methods, description of DFT calculations, preparation of films and solar cells are presented in electronic supporting information (ESI).

\section{Results and Discussion}

\subsection{Synthesis and Structural Characterization}

The new 3,3-di[3-(6-arylcarbazol-9-ylmethyl]oxetanes (4-6) were synthesized in the three synthesis steps as shown in Figure 1. 3-Iodo-9H-carbazole (2) was firstly prepared from commercially available $9 H$-carbazole (1) by using Tucker's iodination procedure [14]. 3,3-Di(3-iodo-9-carbazolylmethyl)oxetane (3) was then synthesized as a key starting material by the reaction of 3,3-di(chloromethyl)oxetane with an excess of 3-iodo-9H-carbazole (2) in the presence of phase transfer catalyst (TBAHS) under basic conditions. Finally, the objec- 
tive derivatives (4-6) were prepared by Suzuki reaction of the key starting diiodo-material 3 with an excess of 4-(diphenylamino)phenylboronic acid, 9-ethyl-9H-carbazole-3-boronic acid pinacol ester or naphthalene-1-boronic acid, correspondingly. The synthesized objective electroactive materials were identified by mass spectrometry, ${ }^{1} \mathrm{H}$ and ${ }^{13} \mathrm{C} \mathrm{NMR}$, and IR spectroscopy (cf. Figure S1). The data were observed to be in good agreement with the theoretical structures. IR spectra of synthesized compounds calculated using DFT method were well correlated with experimental ones (cf. see in ESI).

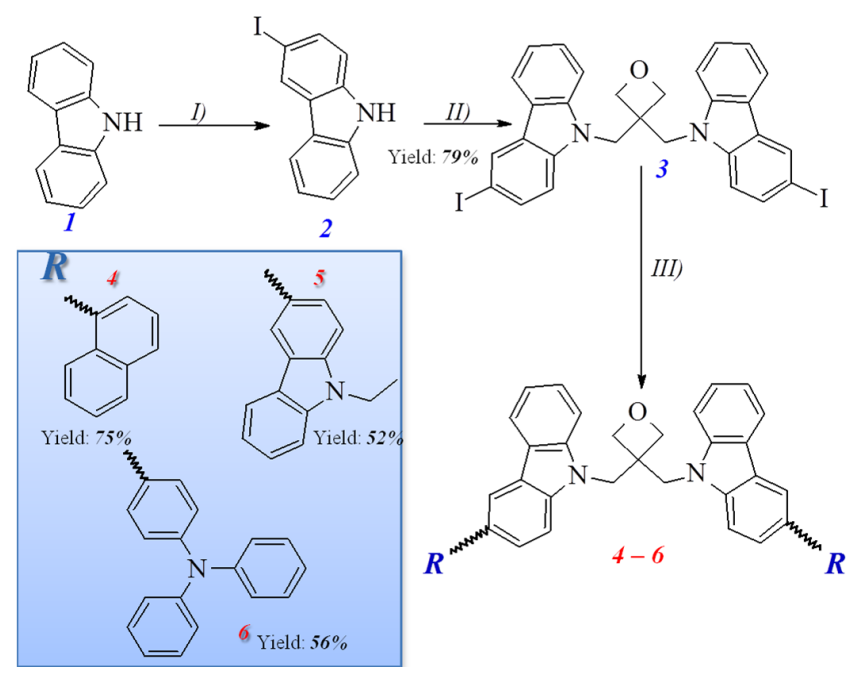

Figure 1. Synthesis of the carbazole-functionalized oxetane derivatives (4-6): (I) $\mathrm{KI}_{1} \mathrm{KIO}_{3}$, (II) $\mathrm{KOH}$, $\mathrm{K}_{2} \mathrm{CO}_{3}$, TBAHS, 3,3-di(chloromethyl)oxetane, (III) $\mathrm{Pd}\left(\mathrm{PPh}_{3}\right)_{2} \mathrm{Cl}_{2}, \mathrm{KOH}$, organoboron derivatives.

The novel oxetane derivatives were soluble in common organic solvents. Transparent thin layers of these derivatives could be prepared on substrates by using spin coating from solutions technology.

\subsection{Thermal Study}

Thermal properties of the synthesized oxetane-based derivatives (4-6) were established under a nitrogen atmosphere using thermogravimetric analysis (TGA) and differential scanning calorimetry (DSC). The results were summarized in Figure 2 (cf. Figures S2 and S3), and the representative DSC thermograms of 4 are presented in Figure $2 b$.
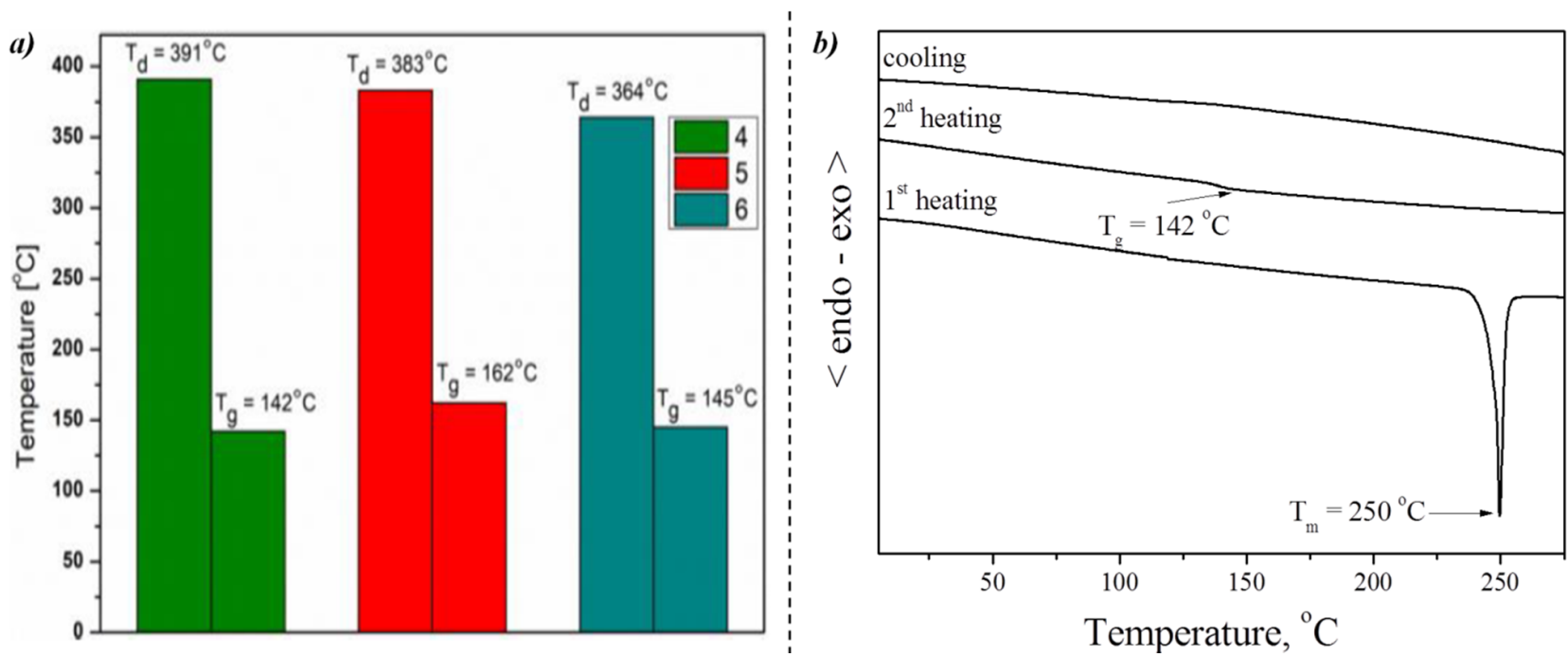

Figure 2. (a) Temperatures of the beginning of decomposition based on $5 \%$ weight loss $\left(\mathrm{T}_{\mathrm{d}}\right)$ from TGA curves and glass transition temperatures $\left(\mathrm{T}_{\mathrm{g}}\right)$ from second heating scan in DSC measurements and (b) DSC curves of the compound 4. 
Compounds (4-6) showed high thermal stability with the onset of thermal decomposition temperatures $\left(\mathrm{T}_{\mathrm{d}}\right)$ above $360^{\circ} \mathrm{C}$. The substitution of carbazole units with naphthalene structures (4) increased $T_{d}$. In the DSC thermogram registered during the first heating of derivative 4 , an endothermic peak due to melting at $250{ }^{\circ} \mathrm{C}$ was observed (cf. Figure $2 \mathrm{~b}$ ).

When the melted sample was cooled down, it was transferred to the amorphous phase with $\mathrm{T}_{\mathrm{g}}$ of $142{ }^{\circ} \mathrm{C}$. Contrary to compounds with naphthalene units, compounds 5 and $\mathbf{6}$ were obtained after synthesis and purification directly as amorphous materials with $\mathrm{T}_{\mathrm{g}}$ of $162{ }^{\circ} \mathrm{C}$ for 5 and $145^{\circ} \mathrm{C}$ for $\mathbf{6}$. The DSC thermograms of compounds 5 and 6 are demonstrated in Figure S3. in ESI. During the second heating scan, also only the glass-transition temperatures $\left(\mathrm{T}_{\mathrm{g}}\right)$ of the amorphous materials were observed, and on further heating, no peaks due to crystallization and melting appeared. The compounds showed high $\mathrm{T}_{\mathrm{g}}$, which is advantageous considering the formation of a uniform and stable film during the PV cell operation at elevated temperature [10].

\subsection{Electrochemical Measurements}

The synthesized carbazole-functionalized oxetane derivatives were examined by cyclic voltammetry $(\mathrm{CV})$ in acetonitrile $\left(\mathrm{CH}_{3} \mathrm{CN}\right)$. The compounds underwent an oxidation process (cf. Figure 3 and Figure S4). HOMO energy level, assuming that the ionization potentials (IP) of ferrocene equals - 5.1 [15], was calculated based on the electrochemical oxidation onset potential (cf. Table 1).
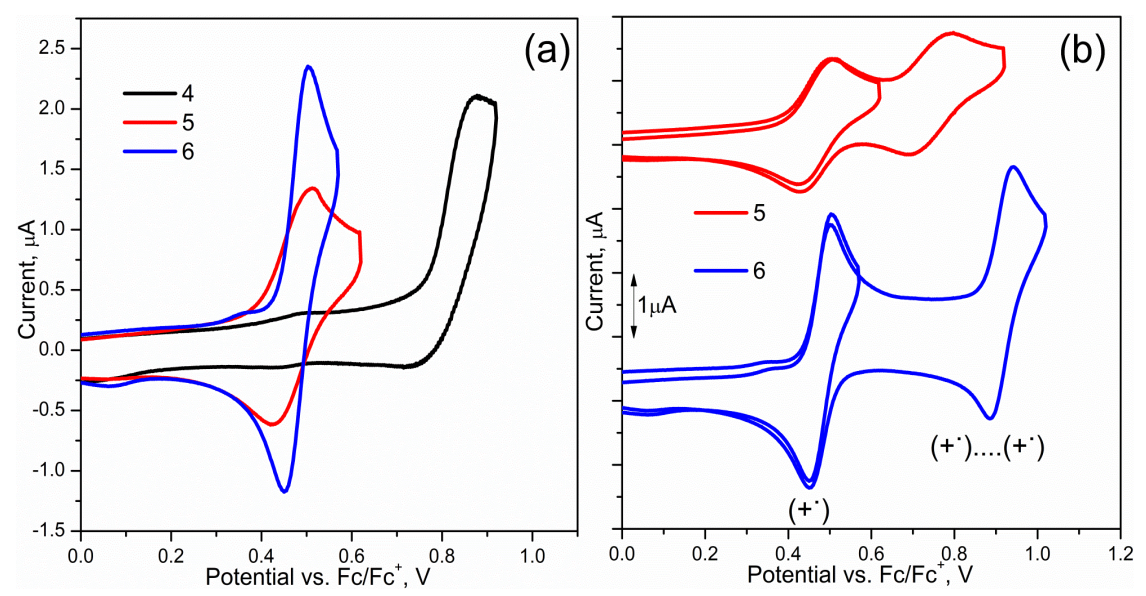

Figure 3. (a) $\mathrm{CV}$ curves of 4,5, 6 in $0.1 \mathrm{M} \mathrm{Bu}_{4} \mathrm{NPF}_{6} / \mathrm{CH}_{3} \mathrm{CN}$ solutions. The measurements were performed with a platinum working electrode $(\mathrm{Pt})$ and referenced against $\mathrm{Fc} / \mathrm{Fc}^{+}$couple, scanning rate $50 \mathrm{mV} / \mathrm{s}$; (b) CV curves of 4 and 5 solution (1st and 2nd oxidation peaks).

Table 1. Electrochemical data for samples 4, 5, 6 recorded in $0.1 \mathrm{M} \mathrm{Bu}_{4} \mathrm{NPF}_{6} / \mathrm{CH}_{3} \mathrm{CN}$ solution.

\begin{tabular}{|c|c|c|c|c|c|c|}
\hline Code & $\begin{array}{c}\text { E }_{\text {ox }}^{\text {onset }} \\
{[\mathrm{V}]}\end{array}$ & $\begin{array}{c}\text { HOMO } \\
{[\mathrm{eV}]}\end{array}$ & $\begin{array}{c}\text { HOMO }^{\text {DFT }} \\
{[\mathrm{eV}]}\end{array}$ & $\begin{array}{c}\mathrm{Eg}_{\mathrm{g}} \mathrm{OPT} \\
{[\mathrm{eV}]}\end{array}$ & $\begin{array}{c}\text { LUMO } \\
{[\mathrm{eV}]}\end{array}$ & $\begin{array}{c}\text { LUMO }^{\text {DFT }} \\
{[\mathrm{eV}]}\end{array}$ \\
\hline 4 & 0.76 & -5.86 & -5.78 & 3.45 & -2.41 & -1.51 \\
\hline 5 & 0.43 & -5.53 & -5.49 & 3.25 & -2.28 & -1.37 \\
\hline 6 & 0.38 & -5.48 & -5.26 & 3.32 & -2.16 & -1.33 \\
\hline
\end{tabular}
and $0.1 \mathrm{M} \mathrm{Bu}_{4} \mathrm{NPF}_{6} / \mathrm{CH}_{3} \mathrm{CN}$.

The reduction process of compounds (4-6) was not observed from 0 to $-2.4 \mathrm{~V}$. In this case, LUMO levels were estimated using the energy gap from the UV-vis spectrum and the optical energy gaps $\left(\mathrm{E}_{\mathrm{g}}{ }^{\mathrm{OPT}}\right.$ ) are in the range from $3.25 \mathrm{eV}$ (5) to $3.45 \mathrm{eV}$ (4). The oxidation process of the molecule with naphthalene substituent (4) was characterized as irreversible behavior (cf. Figure $3 \mathrm{a}$ ), and its oxidation potential $(0.76 \mathrm{~V})$ is higher than others (5 and $\mathbf{6})$.

The oxidation process of derivatives functionalized with 9-ethylcarbazolyl (5) and 4-(diphenylamino)phen (6) was characterized as a quasi-reversible process, with onset 
oxidation potentials at $0.43 \mathrm{~V}(5)$ and $0.38 \mathrm{~V}(6)$, respectively (cf. Table S1). These values correspond with the literature [16-18]. The first oxidation process is assigned to an electron extraction from HOMO. During scanning to a higher potential a second oxidation peak with onsets at $0.68 \mathrm{~V} \mathrm{(5)}$ and $0.86 \mathrm{~V} \mathrm{(6)} \mathrm{(in} \mathrm{the} \mathrm{range} \mathrm{from} 0 \mathrm{~V}$ to $1.6 \mathrm{~V} \mathrm{vs.} \mathrm{Fc} / \mathrm{Fc}^{+}$) were observed (cf. Figure 3b). The ratio of the first oxidation peak to the second is 1:1 in both cases. First, the oxidation potential formed a radical cation $\left(+^{-}\right)$; second, the oxidation potential formed a di-cation $\left(+^{*} \ldots .+^{*}\right)$, or donor groups were oxidized in sequence. Based on the calculated composition of the selected molecular orbitals (cf. Table S2, Figure 4) it can be concluded that HOMO in $\mathbf{4}$ is mainly localized on the carbazolyl moiety, in $\mathbf{5}$ this includes carbazole together with the $N$-ethylcarbazolyl substituent, while in the case of 6, triphenylamine plays a dominant role in the formation of the HOMO level. During several cycles of the oxidation process, oxetane derivatives did not form any product on the surface of an electrode (cf. Figure S4). Comparing the energies of frontier molecular orbitals determined on the basis of electrochemical data with DFT calculated values, it can be noticed that the calculated HOMO energies do not differ much from the experimental values (cf. Table 2).
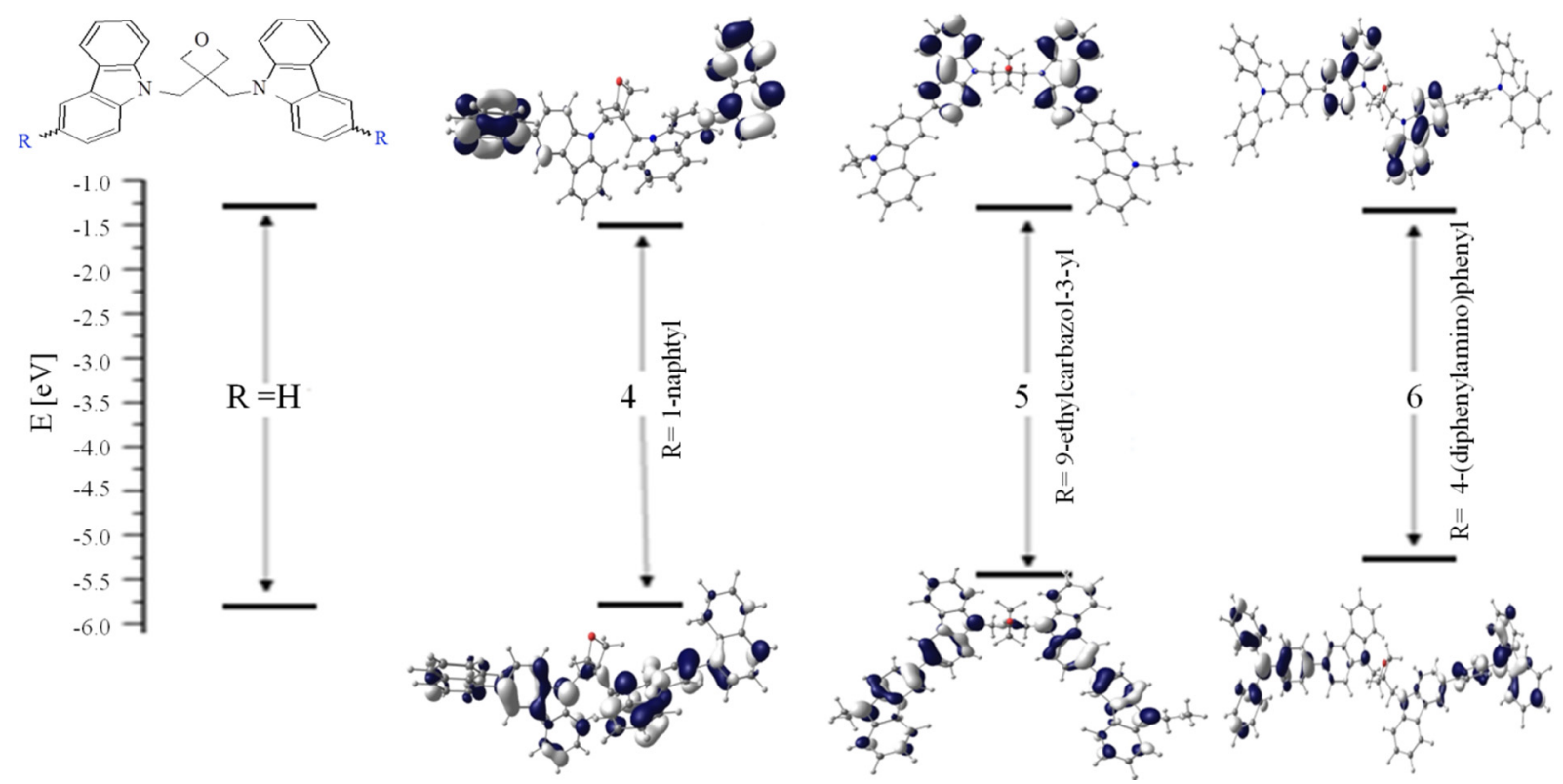

Figure 4. HOMO and LUMO contours and orbital energy changes associated with the introduction of substituents to 3,3-di[3-arylcarbazol-9-ylmethyl]oxetane.

Table 2. DTF results of dipole moments and HOMO, LUMO orbitals energy.

\begin{tabular}{cccc}
\hline Code & Dipole Moment & HOMO & LUMO \\
\hline $\mathbf{4}$ & 2.62 & -5.78 & -1.51 \\
$\mathbf{5}$ & 3.89 & -5.26 & -1.33 \\
$\mathbf{6}$ & 4.86 & -5.49 & -1.37 \\
\hline
\end{tabular}

In the case of LUMO the differences are greatly pronounced as can be expected, but the same tendency, that is, the lowering of LUMO in the following order: 6, 5, 4 was seen. Based on energy changes in the frontier orbitals energy (Figure 4), it can be concluded that the strongest electron-donating property is shown by 4-(diphenylamino)phenyl substituent, and the lowest by 1-naphtyl. Considering the HOMO energy level of the investigated compounds it seems that oxetane with triphenylamine unit (6) is the most thermodynamically capable of extracting holes from perovskite, with a valence band edge at around $5.4 \mathrm{eV}$ [19]. On the other hand, the LUMO levels of oxetane derivatives around $-2.3 \mathrm{eV}$ can effectively block electron transport from perovskite to the Au electrode, preventing carrier 
recombination at the anode [20]. Thus, the LUMO levels are higher than the conduction band of perovskite, making them good electron blocking materials.

\subsection{Photophysical Investigations}

UV-Vis absorption and photoluminescence (PL) spectra of synthesized molecules were measured in the solvents with various polarities (chloroform $<$ chlorobenzene $<$ dichloromethane $<$ methanol $<$ acetonitrile), in the solid state as a thin film on glass substrate and as powders. The measurements were performed in the same conditions and the same compound concentrations. The obtained spectroscopic data are listed in Table 3, whereas the UV-Vis and PL spectra are depicted in Figure 4 and Figures S5-S8 in ESI.

Table 3. The UV-Vis and PL spectroscopic parameters of the synthesized oxetane derivatives.

\begin{tabular}{|c|c|c|c|c|c|c|}
\hline Code & Medium $^{\text {a }}$ & $\begin{array}{c}\lambda_{\max }[\mathrm{nm}] \\
\left(\varepsilon \cdot 10^{4}\right)^{b}\end{array}$ & $\lambda_{\mathrm{ex}}[\mathrm{nm}]$ & $\lambda_{\mathrm{em}}[\mathrm{nm}]$ & $\begin{array}{l}\text { PL } \\
\text { Stokes Shift }{ }^{c}\left[\mathrm{~cm}^{-1}\right]\end{array}$ & $\Phi_{P L}(\%)$ \\
\hline \multirow{7}{*}{4} & $\mathrm{CHCl}_{3}$ & $\begin{array}{c}272^{\text {sh }} \\
296(13.4), 345^{\text {sh }}\end{array}$ & $263^{\mathrm{sh}}, 300,350^{\mathrm{sh}}$ & $360^{\mathrm{sh}}, 373,716,746$ & 6974 & 19 \\
\hline & $\mathrm{PhCl}$ & $297(5.0), 345 \mathrm{sh}$ & 300,350 sh & $360^{\mathrm{sh}}, 373,714,746$ & 6860 & - \\
\hline & $\mathrm{CH}_{2} \mathrm{Cl}_{2}$ & $296(7.3), 345 \mathrm{sh}$ & $262, \mathbf{3 0 0}, 345^{\mathrm{sh}}$ & $360^{\mathrm{sh}}, 374,714,746$ & 7046 & 31.9 \\
\hline & $\mathrm{CH}_{3} \mathrm{OH}$ & $293(10.4), 345^{\mathrm{sh}}$ & $262^{\mathrm{sh}}, \mathbf{3 0 0}, 345^{\mathrm{sh}}$ & $360^{\text {sh }}, 374,714,746$ & 7392 & - \\
\hline & $\mathrm{CH}_{3} \mathrm{CN}$ & $273(14.1), 345^{\mathrm{sh}}$ & $262,300,315^{\mathrm{sh}}, 345^{\mathrm{sh}}$ & $360^{\text {sh }}, \mathbf{3 8 0}, 719,751$ & 10,314 & 87.0 \\
\hline & Film & 351 & 349 & 381 & 2243 & 9.0 \\
\hline & Powder & - & 260,355 & $372^{\text {sh }}, 397$ & - & - \\
\hline \multirow{7}{*}{5} & $\mathrm{CHCl}_{3}$ & $300(11.8), 345^{\mathrm{sh}}$ & $286^{\text {sh }}, 302,345^{\text {sh }}$ & $390^{\text {sh }}, 410,773,820$ & 8943 & 2.1 \\
\hline & $\mathrm{PhCl}$ & $297(11.9), 345 \mathrm{sh}$ & $300^{\text {sh }}, \mathbf{3 1 0}, 343^{\text {sh }}$ & $390^{\mathrm{sh}}, \mathbf{4 1 0}, \mathbf{7 8 0}, 820$ & 9278 & - \\
\hline & $\mathrm{CH}_{2} \mathrm{Cl}_{2}$ & $300(11.9), 345 \mathrm{sh}$ & $265,286^{\mathrm{sh}}, 306,342^{\mathrm{sh}}$ & $390^{\text {sh }}, \mathbf{4 1 0}, 778,815$ & 8943 & 23.6 \\
\hline & $\mathrm{CH}_{3} \mathrm{OH}$ & $300(14.4), 345 \mathrm{sh}$ & $264,284^{\text {sh }}, 303,343^{\text {sh }}$ & $390^{\mathrm{sh}}, 408,773,815$ & 8943 & - \\
\hline & $\mathrm{CH}_{3} \mathrm{CN}$ & $295(12.6), 345^{\mathrm{sh}}$ & $262,305,342^{\text {sh }}$ & $390^{\text {sh }}, 409,776,820$ & 9508 & 25.5 \\
\hline & Film & $311^{\mathrm{sh}}, 360$ & $305,348^{\text {sh }}, 359 \mathrm{sh}$ & $397^{\text {sh }}, 419$ & 3911 & 4.2 \\
\hline & Powder & - & 261,299 sh $, 334^{\text {sh }}, 369$ & 418 & - & - \\
\hline \multirow{7}{*}{6} & $\mathrm{CHCl}_{3}$ & $277^{\mathrm{sh}}, 326(7.5)$ & 335 & $400,775,802$ & 11,101 & 4.3 \\
\hline & $\mathrm{PhCl}$ & 290(11.6), $338 \mathrm{sh}$ & 335 & $400,776,805$ & 9483 & - \\
\hline & $\mathrm{CH}_{2} \mathrm{Cl}_{2}$ & $273^{\mathrm{sh}}, 328(6.6)$ & $274,300 \mathrm{sh}, 315^{\mathrm{sh}}, 330$ & $406,782,797$ & 5857 & 43.0 \\
\hline & $\mathrm{CH}_{3} \mathrm{OH}$ & $273^{\text {sh }}, 323(12.2)$ & $300^{\mathrm{sh}}, 315^{\mathrm{sh}}, 342$ & $406,771,793$ & 6329 & - \\
\hline & $\mathrm{CH}_{3} \mathrm{CN}$ & $\begin{array}{c}275^{\mathrm{sh}}, 302^{\mathrm{sh}} \\
323(8.4)\end{array}$ & $300^{\mathrm{sh}}, 315^{\mathrm{sh}}, 330$ & $409,780,808$ & 6510 & 42.8 \\
\hline & Film & 350 & 308,330 sh & 403 & 3757 & 7.2 \\
\hline & Powder & - & 384,398 sh & 414 & - & - \\
\hline
\end{tabular}

a Dielectric constant of solvents: chloroform $\left(\mathrm{CHCl}_{3}, \varepsilon=4.89\right)$, chlorobenzene $(\mathrm{PhCl}, \varepsilon=5.62)$, dichloromethane $\left(\mathrm{CH}_{2} \mathrm{Cl}_{2}, \varepsilon=8.93\right)$, methanol $\left(\mathrm{CH}_{3} \mathrm{OH}, \varepsilon=32.66\right)$ and acetonitrile $\left(\mathrm{CH}_{3} \mathrm{CN}, \varepsilon=35.94\right) .{ }^{\mathbf{b}}$ Molar absorption coefficient $\left(\mathrm{dm}^{3} / \mathrm{mol} \cdot \mathrm{cm}\right){ }^{\mathbf{c}}$ Stokes shifts calculated according to the equation $\Delta v=\left(1 / \lambda_{\max }-1 / \lambda_{\mathrm{em}}\right) \cdot 10^{7}\left[\mathrm{~cm}^{-1}\right]$. sh were equal $10^{-5} \mathrm{~mol} / \mathrm{dm}^{3}$.

Investigated compounds absorbed in the range of $250 \mathrm{~nm}$ to $380 \mathrm{~nm}$ with one dominating band. They show optical energy band gaps $\left(\mathrm{E}_{\mathrm{g}}{ }^{\mathrm{OPT}}\right)$ in the range of $3.25-3.45 \mathrm{eV}$. Low absorption and a rather wide band gap of the hole transporting material is beneficial in reducing the optical losses [21]. Considering the absorption, excitation, and emission spectra of the functionalized oxetane derivatives in various solvents (cf. Figure $4 \mathrm{a}$ and Figure S5), the effect of the carbazole substituents chemical structure is pronounced. The molecules with 1-naphtyl (4) and 9-ethylcarbazol-3-yl (5) substituents exhibited absorption bands with maximum $\left(\lambda_{\max }\right)$ at about $273-300 \mathrm{~nm}$, while $\lambda_{\max }$ of the compound with a 4-(diphenylamino)phenyl units (6) was shifted to $\sim 325 \mathrm{~nm}$ (cf. Table 3, Figure S5). In the UV-Vis spectra of compound 4 the $\lambda_{\max }$ located at 293-297 $\mathrm{nm}$ was dominating, except in acetonitrile where $\lambda_{\max }=273 \mathrm{~nm}$. It should be noted that the observed changes are visible only for this derivative and only in acetonitrile (cf. Figure S6a). Therefore, it may indicate a strong interaction between the compound with the naphthalene substituent 
and the solvents such as acetonitrile $[22,23]$. The calculated absorption spectra in acetonitrile, dichloromethane, chlorobenzene and chloroform solvents exhibit differences in the band maxima only in the case of compound 4 ; in $\mathbf{5}$ and $\mathbf{6}$ the differences are negligible (cf. Figure S6a). A small solvatochromic effect visible in the case of 4 and practically no changes in the band maxima on absorption spectra of $\mathbf{5}$ and $\mathbf{6}$ in solvents with different polarity is likely associated with relatively small changes in the dipole moments between the ground and first excited states. In the case of compound 4, the change in the dipole moment between states $S_{0}$ and $S_{1}$ is $0.7 \mathrm{D}$, and for compounds 5 and $\mathbf{6}$, these values are 0.03 and $0.25 \mathrm{D}$, respectively (cf. Table S3). Moreover, only in the case of compound 4, the influence of the solvent polarity on the emission quantum yield $\left(\Phi_{\mathrm{CH} 2 \mathrm{Cl} 2}=31.8 \%, \Phi_{\mathrm{CH} 3 \mathrm{CN}}\right.$ $=87 \%$, cf. Table 3) is noticeable, in the other two cases the changes in the quantum yield between methylene chloride and acetonitrile solutions are negligible. According to the TD-DF calculation, the excitation electronic transitions $\left(\lambda_{\mathrm{ex}}=300 \mathrm{~nm}(4), 306 \mathrm{~nm}(5)\right.$ and $330 \mathrm{~nm}(6)$ in $\mathrm{CH}_{2} \mathrm{Cl}_{2}$ ) correspond to the $\mathrm{H}-2 / \mathrm{H}-1 / \mathrm{HOMO} \rightarrow \mathrm{LUMO} / \mathrm{L}+1 / \mathrm{L}+2 / \mathrm{L}+3$ type (cf. Table S4). Taking into account the nature of the energy levels involved in these transitions, it can be seen that in the case of 4 the excitation has intramolecular charge transfer nature $\left(\boldsymbol{\pi}_{\text {carbazole }} \rightarrow \pi_{\mathrm{R}}{ }^{*}\right)$ and in $\mathbf{5}$ and $\mathbf{6}$ the excitation has mixed intramolecular charge transfer/locally-excited (ICT/LE) character $\left(\pi_{\text {carbazole }}+\pi_{\mathrm{R}} \rightarrow \pi_{\mathrm{R}}{ }^{*}\right)$. The absorption spectra of the compounds in the film compared to the solution spectra showed bathochromic shifts due to molecular packing in the solid state.

The emission and excitation spectra were registered and for the most intense PL band in the selected media the PL quantum yield ( $\left.\Phi_{\mathrm{PL}}\right)$ was measured (cf. Table 3$)$. The functionalized oxetane derivatives emitted in the near-ultraviolet and the violet spectral range with the main maximum emission band $\left(\lambda_{\mathrm{em}}\right)$ located in the range of $373-419 \mathrm{~nm}$. However, a weak second emission band with the $\lambda_{\mathrm{em}}$ at lower energies was also observed. This behavior was also noticed and presented in a previous paper [24], but in that case, the presence of the low-energy emission band was due to the presence of copper ions. In order to explain the presence of the second PL band, DFT calculations were performed. The first singlet and triplet excited states were optimized and, the calculated energy differences between $T_{1}$ and $S_{0}$ states corresponded to the long-wave band on the emission spectra (cf. Table S3). So, the presence of this low-energy band indicates the processes of internal conversion of the excited state, and the compounds exhibit phosphorescence at room temperature.

An influence of solvent polarity on the positions of $\lambda_{\max }$ and $\lambda_{\mathrm{em}}$ was not seen, thus the solvatochromism effect was not observed (cf. Figure $5 b$ and Figure S6). However, the influence of polarity on the quantum yield was noticeable (cf. Table 3). In the chloroform solution weak PL was noted, while in dichloromethane or acetonitrile PL intensity significantly increased. The quantum yield in chloroform ranged from $2.1 \%$ to $19 \%$, while in acetonitrile quantum yield ranged from $25.5 \%$ to $87 \%$. Moreover, the PL intensity dependencies on the dielectric constant of the solvents were also visible in the recorded spectra at different excitation wavelengths (cf. Figure S7). The influence of polarity on the quantum yield of oxetane derivatives was reported in other works [25]. The slightly bathochromic shift of the $\lambda_{\mathrm{em}}$ in the films and powders relative to the solutions were observed (cf. Table 3). 
(a)
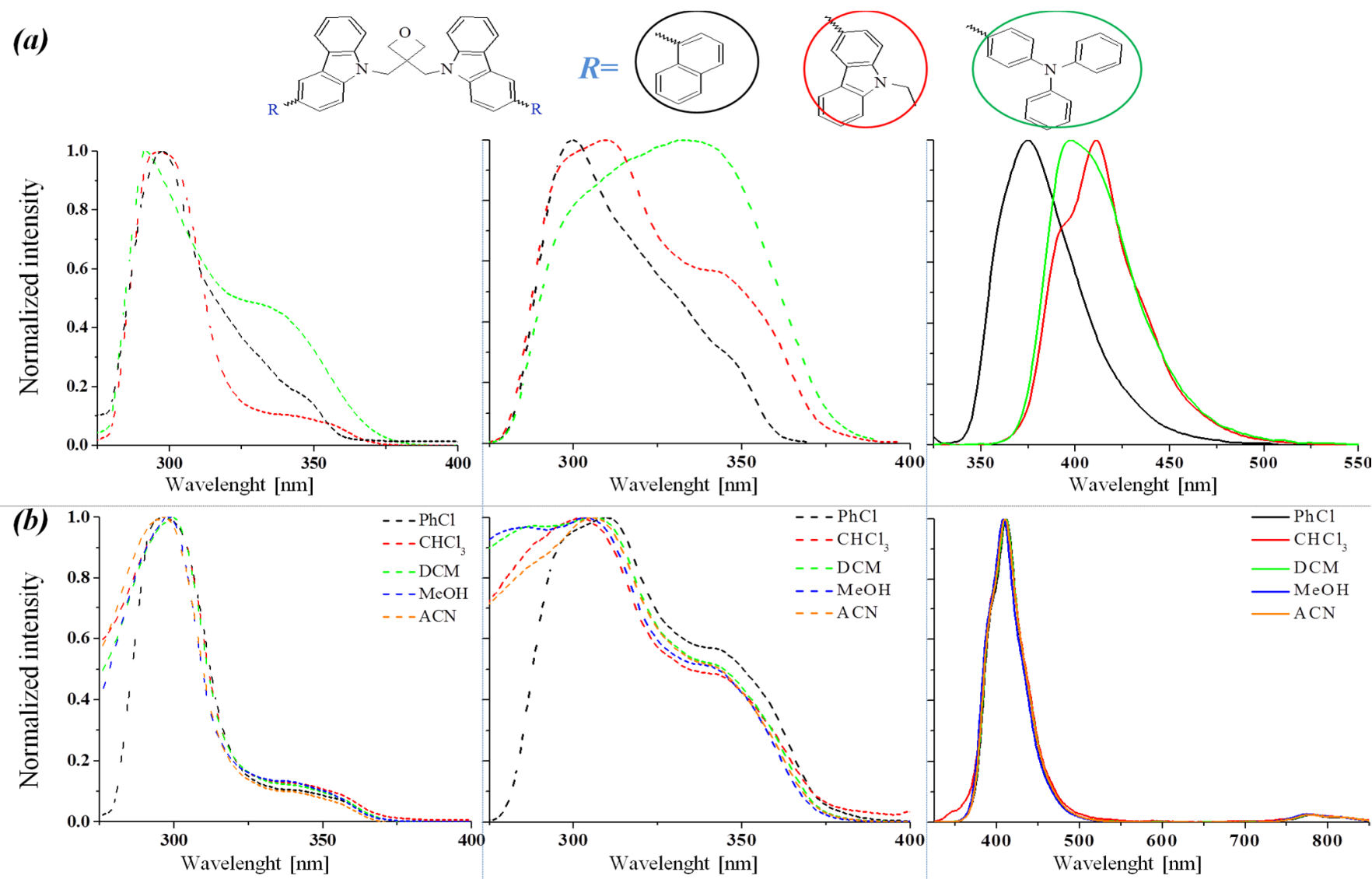

Figure 5. Imposed UV-Vis and excitation spectra (dotted line) as well as PL spectra (solid line) for: (a) compounds (4, $5,6)$ in chlorobenzene $(\mathrm{PhCl}) ;(\mathbf{b})$ compound 5 in various solvents such as: chloroform $\left(\mathrm{CHCl}_{3}\right)$, chlorobenzene $(\mathrm{PhCl})$, dichloromethane $\left(\mathrm{CH}_{2} \mathrm{Cl}_{2}\right)$, methanol $\left(\mathrm{CH}_{3} \mathrm{OH}\right)$ and acetonitrile $\left(\mathrm{CH}_{3} \mathrm{CN}\right)$.

Additionally, the effect of the aggregation phenomenon on optical properties of functionalized oxetane derivatives in a binary mixture of $\mathrm{CH}_{3} \mathrm{CN} / \mathrm{H}_{2} \mathrm{O}$ with increasing water content $\left(f_{w}=0 \%, 10 \%, 20 \%, 30 \%, 40 \%, 50 \%, 60 \%, 70 \%, 80 \%, 90 \%, v / v\right)$ was investigated. The obtained results are shown in Figure 6 and Figure S9 in ESI. Measurements were carried out using four different excitation wavelengths $\left(\lambda_{\text {ex }}\right): 300,320,340,360 \mathrm{~nm}$. All compounds showed a trend towards aggregation-caused quenching (ACQ), where increasing the water content in the $\mathrm{CH}_{3} \mathrm{CN} / \mathrm{H}_{2} \mathrm{O}$ system above $40 \%$ (in the case of 6 above $30 \%$ ) caused a reduction in the emission intensity [26-28] (cf. Figure 6). Moreover, it can be seen that in the aggregation state (from $50 \%$ to $90 \% v / v$ of water content), compound 6 with 4-(diphenylamino)phenyl units have shown a similar emission intensity for different $\lambda_{\mathrm{ex}}$ in contrast to molecules with 1-naphthyl (4) and 9-ethylcarbazolyl (5) substituents. The aggregation investigations have demonstrated that different water content in the $\mathrm{CH}_{3} \mathrm{CN} / \mathrm{H}_{2} \mathrm{O}$ system did not affect the $\lambda_{\mathrm{em}}$ (cf. Figure S9). 


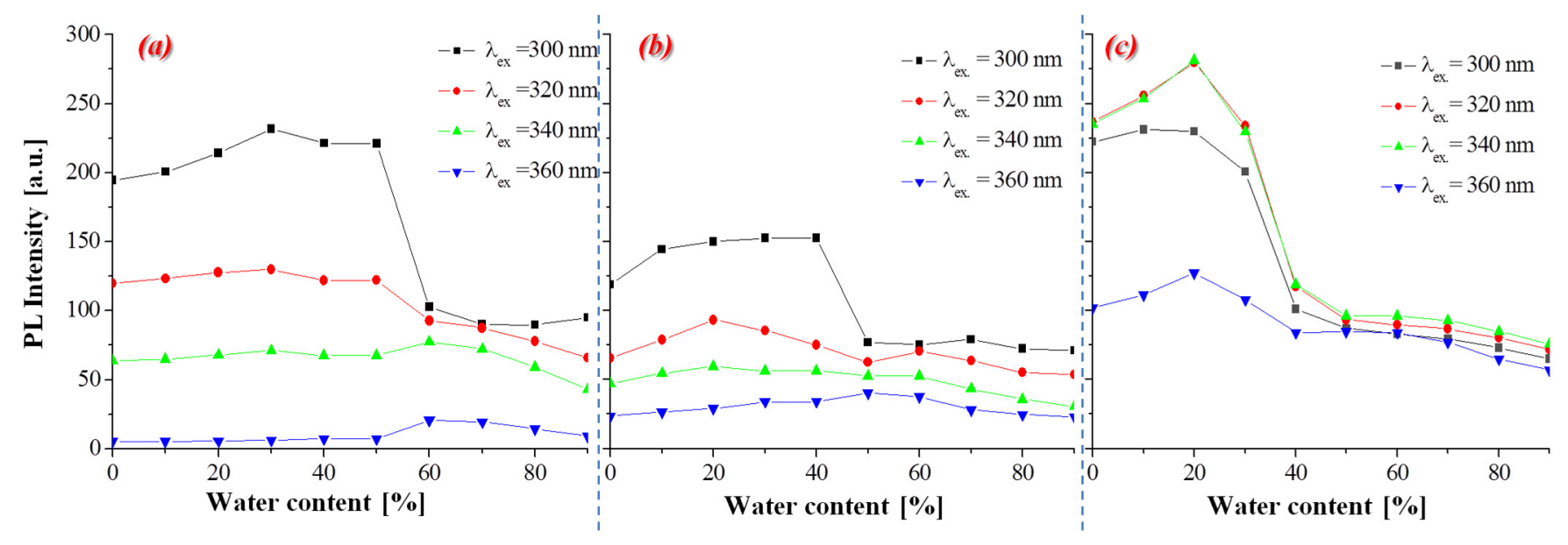

Figure 6. Changes in the PL intensity versus the water content $\left(f_{w}\right)$ in a binary mixture of $\mathrm{CH}_{3} \mathrm{CN} / \mathrm{H}_{2} \mathrm{O}$ with an increasing water content $\left(f_{w}=0 \%, 10 \%, 20 \%, 30 \%, 40 \%, 50 \%, 60 \%, 70 \%, 80 \%, 90 \%, v / v\right)$ at different excitation wavelengths $\left(\lambda_{\text {ex }} .300\right.$, 320, 340, $360 \mathrm{~nm}$ ) for: (a) 4, (b) 5, (c) 6 (cf. Figure S12).

\subsection{Photovoltaic Characterization}

The synthesized oxetane derivatives were tested as hole transporting materials in perovskite solar cells to find the effect of carbazole substituent structure on device performance. Prior to solar cell fabrication, the surface quality of the prepared layers was evaluated using an atomic force microscope (AFM), and the root-mean-square (RMS) parameter was determined. For this purpose, RMS values were determined for the following layers: $\mathrm{FTO} / \mathrm{b}-\mathrm{TiO}_{2} / \mathrm{m}-\mathrm{TiO}_{2}, \mathrm{FTO} / \mathrm{b}-\mathrm{TiO}_{2} / \mathrm{m}-\mathrm{TiO}_{2} /$ perovskite, and the last one was $\mathrm{FTO} / \mathrm{b}-\mathrm{TiO}_{2} / \mathrm{m}-\mathrm{TiO}_{2} /$ perovskite/HTM and the AFM micrograms are given in Figure $7 \mathrm{~b}-\mathrm{g}$. The perovskite layers were obtained by the two-step method and the details are given in ESI. According to the predictions, the smoothest layer was $\mathrm{FTO} / \mathrm{b}-\mathrm{TiO}_{2} / \mathrm{m}-\mathrm{TiO}_{2}$ with $\mathrm{RMS}$ values in the range of $20-25 \mathrm{~nm}$. After applying perovskite, the layers' roughness increased significantly to values of $170-180 \mathrm{~nm}$. Next, it was found that the oxetane derivatives fully covered the perovskite surface and reduced its surface fluctuation. The RMS value was reduced to 45, 40 and $55 \mathrm{~nm}$ for compounds 4, 5, and 6, respectively. A beneficial effect of perovskite surface smoothing due to the presence of oxetane derivatives on the short-circuit current density $\left(\mathrm{J}_{\mathrm{sc}}\right)$ and open-circuit voltage $\left(\mathrm{V}_{\mathrm{oc}}\right)$ is expected. 


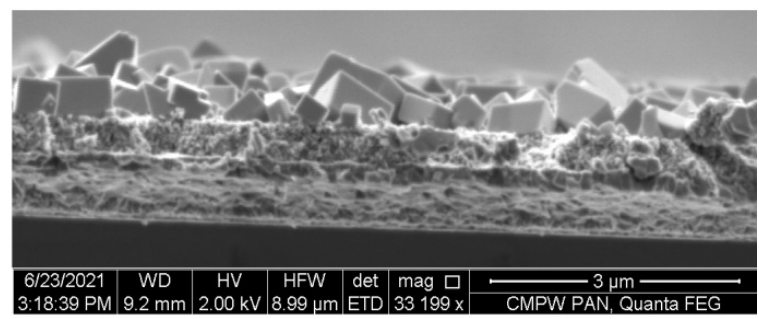

(a)

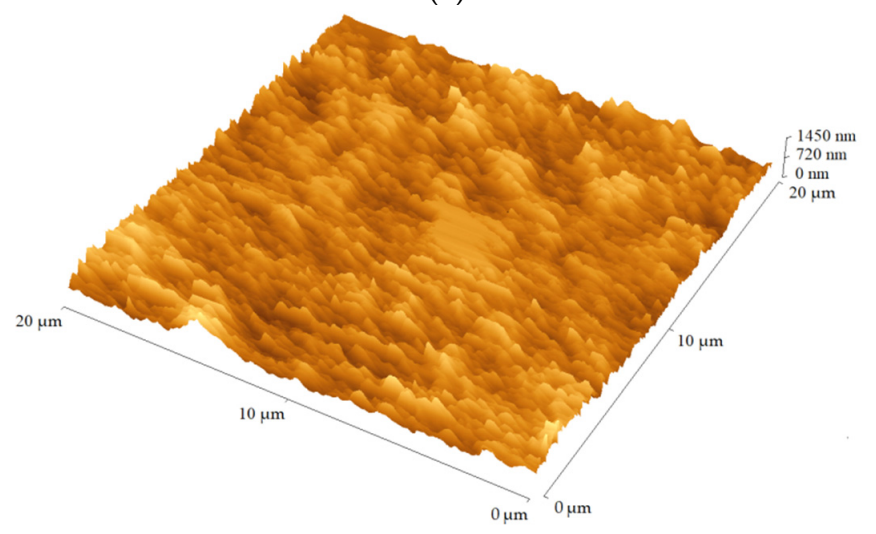

(c)

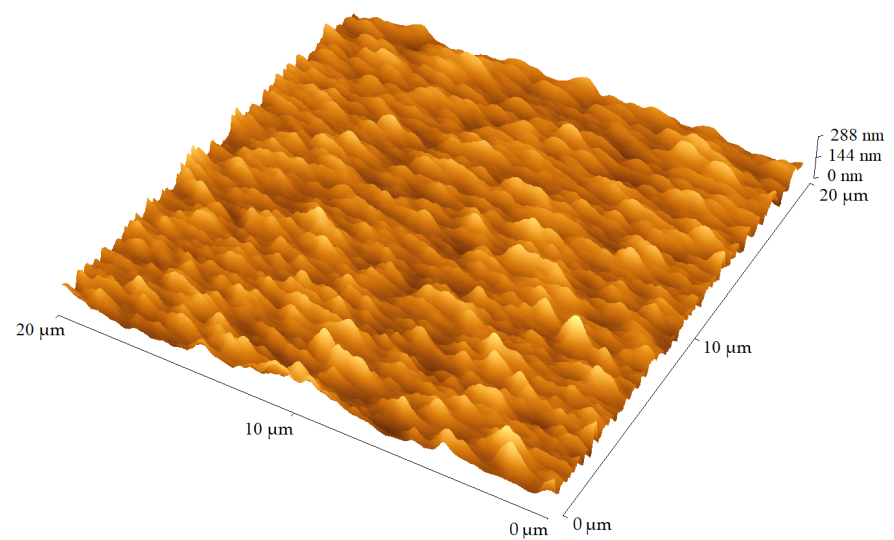

(e)

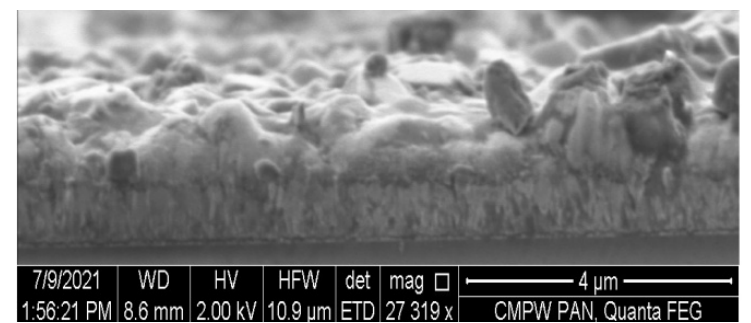

(b)

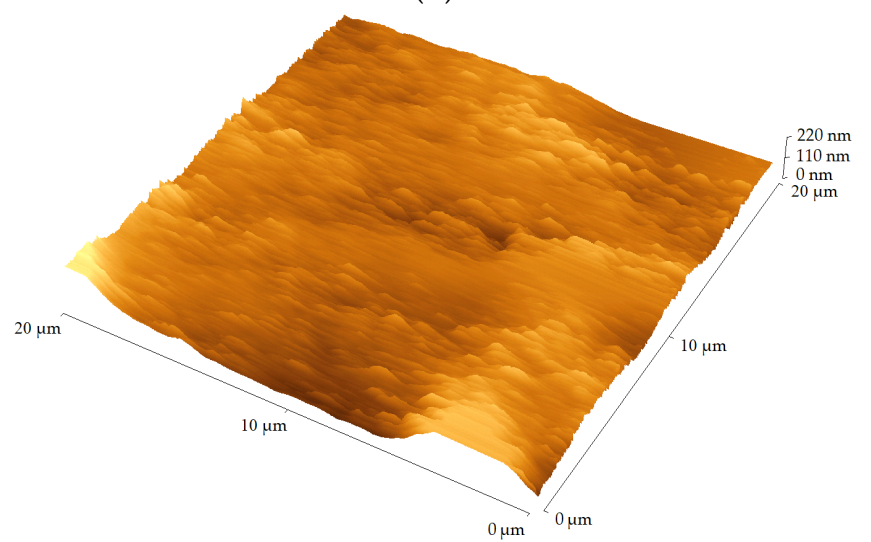

(d)

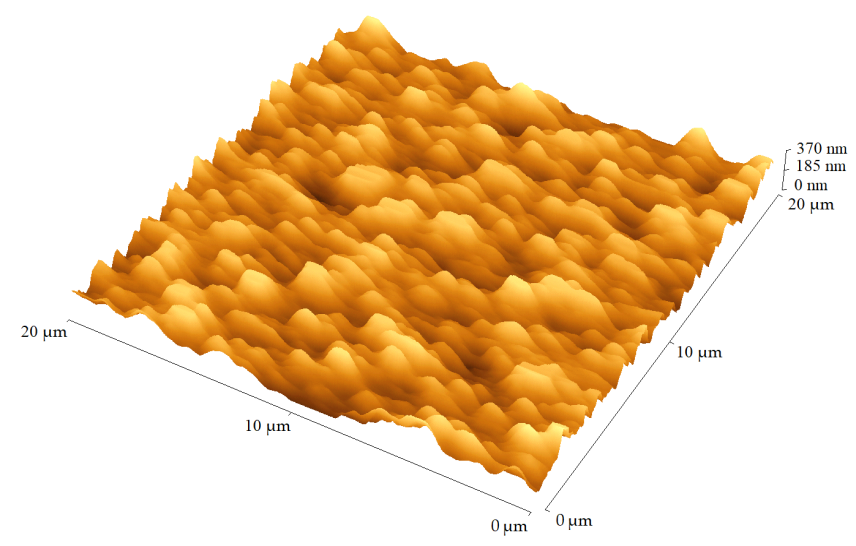

(f)

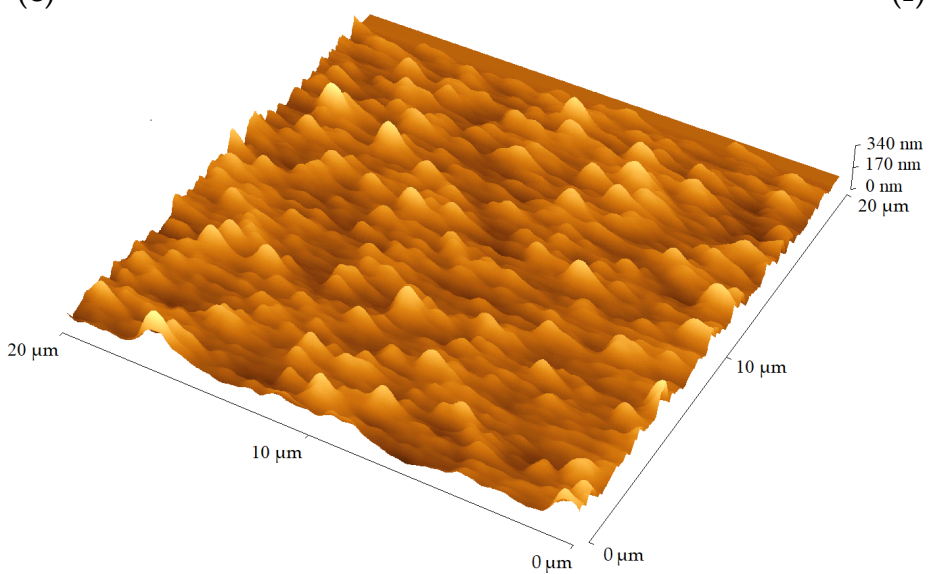

(g)

Figure 7. Cross-section SEM image of the reference (a) $\mathrm{FTO} / \mathrm{b}-\mathrm{TiO}_{2} / \mathrm{m}-\mathrm{TiO}_{2} /$ perovskite and with $\mathrm{HTM}(\mathbf{b}) \mathrm{FTO} / \mathrm{b}-\mathrm{TiO} 2 / \mathrm{m}$ $\mathrm{TiO}_{2} /$ perovskite/HTM (on the right) perovskite solar cells and the AFM micrograms of (c) FTO/b-TiO $/ 2 / \mathrm{m}-\mathrm{TiO}$, $(\mathbf{d})$ $\mathrm{FTO} / \mathrm{b}-\mathrm{TiO}_{2} / \mathrm{m}-\mathrm{TiO}_{2} /$ perovskite, (e) $\mathrm{FTO} / \mathrm{b}-\mathrm{TiO}_{2} / \mathrm{m}-\mathrm{TiO}_{2} /$ perovskite $/ 4$ (with $17.50 \mu \mathrm{L} \mathrm{Li}-\mathrm{TFSI}$ ), (f) $\mathrm{FTO} / \mathrm{b}-\mathrm{TiO} / 2 \mathrm{~m}-$ $\mathrm{TiO}_{2} /$ perovskite $/ 6$ (with $35.00 \mu \mathrm{L} \mathrm{Li}-\mathrm{TFSI}$ ) and (g) $\mathrm{FTO} / \mathrm{b}-\mathrm{TiO}_{2} / \mathrm{m}-\mathrm{TiO}_{2} /$ perovskite $/ \mathbf{5}$ (with $8.75 \mu \mathrm{L} \mathrm{Li}$-TFSI). 
Non-encapsulated devices with the structure $\mathrm{FTO} / \mathrm{b}-\mathrm{TiO}_{2} / \mathrm{m}-\mathrm{TiO}_{2} /$ perovskite/HTM/ $\mathrm{Au}$ were fabricated. Additionally, the reference solar cell without oxetane derivatives was also prepared (cf. Figure 7a). The details of the PSCs' construction are described in the ESI. The cross-sectional scanning electron microscopy (SEM) images of the reference device and devices with oxetane derivatives are presented in Figure 7a. The HTM layer was doped with the most common additive of lithium bis(trifluoromethanesulfonyl)imide (Li-TFSI). Different doping volumes of $\mathrm{Li}^{+}: 8.75,17.50$ and $35.00 \mu \mathrm{L}$ were applied to find the optimal amount of dopant to give the best PV performance. The calculated photovoltaic parameters $\left(\mathrm{J}_{\mathrm{sc}}\right.$ - short-circuit current, $\mathrm{V}_{\mathrm{oc}}$-open-circuit voltage, $\mathrm{FF}$-fill factor, and PCEpower conversion efficiency) based on current-voltage (I-V) characteristics of the prepared devices are collected in Table 4 . The I-V characteristics were registered in a forward and backward scan (measurements were conducted in the Standard Test Conditions) and the $\mathrm{I}-\mathrm{V}$ characteristics for champion devices are presented in ESI as Figure S10.

Table 4. Photovoltaic properties of fabricated perovskite solar cells.

\begin{tabular}{|c|c|c|c|c|c|c|}
\hline Device Structure & $\begin{array}{c}\text { V }_{\text {Li-TFSI }} \\
{[\mu \mathrm{L}]}\end{array}$ & $\begin{array}{c}I_{s c} \\
{[\mathrm{~mA}]}\end{array}$ & $\begin{array}{c}\mathrm{J}_{\mathrm{sc}} \\
{\left[\mathrm{mA} / \mathrm{cm}^{2}\right]}\end{array}$ & $\begin{array}{c}\mathrm{V}_{\mathrm{oc}} \\
{[\mathrm{mV}]}\end{array}$ & $\begin{array}{l}\text { FF } \\
{[-]}\end{array}$ & $\begin{array}{l}\text { PCE } \\
{[\%]}\end{array}$ \\
\hline $\begin{array}{c}\mathrm{FTO} / \mathrm{b}-\mathrm{TiO}_{2} / \mathrm{m}-\mathrm{TiO}_{2} / \text { perovskite/Au } \\
\text { Champion } \\
\text { Forward } \\
\text { Backward }\end{array}$ & - & $\begin{array}{c}2.15 \\
2.18 \pm 0.04 \\
1.89 \pm 0.67\end{array}$ & $\begin{array}{c}8.60 \\
8.71 \pm 0.16 \\
7.58 \pm 2.67\end{array}$ & $\begin{array}{c}393.9 \\
362.1 \pm 72.6 \\
355.4 \pm 173.5\end{array}$ & $\begin{array}{c}0.28 \\
0.28 \pm 0.00 \\
0.23 \pm 0.04\end{array}$ & $\begin{array}{c}1.11 \\
1.01 \pm 0.24 \\
0.72 \pm 0.48\end{array}$ \\
\hline $\begin{array}{c}\mathrm{FTO} / \mathrm{b}-\mathrm{TiO}_{2} / \mathrm{m}^{-\mathrm{TiO}_{2}} / \text { perovskite } / 4 / \mathrm{Au} \\
\text { Champion } \\
\text { Forward } \\
\text { Backward }\end{array}$ & 8.75 & $\begin{array}{c}2.79 \\
2.65 \pm 0.30 \\
2.20 \pm 0.07 \\
\end{array}$ & $\begin{array}{c}11.14 \\
10.59 \pm 1.21 \\
8.81 \pm 0.30\end{array}$ & $\begin{array}{c}514.3 \\
509.6 \pm 6.2 \\
475.9 \pm 22.4\end{array}$ & $\begin{array}{c}0.26 \\
0.27 \pm 0.01 \\
0.25 \pm 0.01 \\
\end{array}$ & $\begin{array}{c}1.53 \\
1.46 \pm 0.09 \\
1.07 \pm 0.06\end{array}$ \\
\hline $\begin{array}{c}\mathrm{FTO} / \mathrm{b}-\mathrm{TiO}_{2} / \mathrm{m}^{-\mathrm{TiO}_{2}} / \text { perovskite } / 4 / \mathrm{Au} \\
\text { Champion } \\
\text { Forward } \\
\text { Backward }\end{array}$ & 17.50 & $\begin{array}{c}3.28 \\
3.11 \pm 0.36 \\
2.52 \pm 0.07\end{array}$ & $\begin{array}{c}13.13 \\
12.43 \pm 1.43 \\
10.10 \pm 0.26\end{array}$ & $\begin{array}{c}541.6 \\
527.4 \pm 16.1 \\
522.9 \pm 31.8\end{array}$ & $\begin{array}{c}0.26 \\
0.25 \pm 0.02 \\
0.23 \pm 0.01\end{array}$ & $\begin{array}{c}1.86 \\
1.65 \pm 0.33 \\
1.25 \pm 0.07\end{array}$ \\
\hline $\begin{array}{c}\mathrm{FTO} / \mathrm{b}-\mathrm{TiO}_{2} / \mathrm{m}-\mathrm{TiO}_{2} / \text { perovskite} / 4 / \mathrm{Au} \\
\text { Champion } \\
\text { Forward } \\
\text { Backward }\end{array}$ & 35.00 & $\begin{array}{c}3.18 \\
3.04 \pm 0.26 \\
2.32 \pm 0.23\end{array}$ & $\begin{array}{c}12.70 \\
12.14 \pm 1.06 \\
9.29 \pm 0.90\end{array}$ & $\begin{array}{c}544.8 \\
561.4 \pm 32.70 \\
514.0 \pm 12.44\end{array}$ & $\begin{array}{c}0.25 \\
0.25 \pm 0.01 \\
0.23 \pm 0.01\end{array}$ & $\begin{array}{c}1.77 \\
1.70 \pm 0.11 \\
1.10 \pm 0.09\end{array}$ \\
\hline $\begin{array}{c}\mathrm{FTO} / \mathrm{b}-\mathrm{TiO}_{2} / \mathrm{m}^{-\mathrm{TiO}_{2}} / \text { perovskite } / 5 / \mathrm{Au} \\
\text { Champion } \\
\text { Forward } \\
\text { Backward }\end{array}$ & 8.75 & $\begin{array}{c}1.36 \\
1.37 \pm 0.03 \\
1.13 \pm 0.31 \\
\end{array}$ & $\begin{array}{c}5.45 \\
5.50 \pm 0.11 \\
4.51 \pm 1.24\end{array}$ & $\begin{array}{c}450.8 \\
446.7 \pm 10.2 \\
428.4 \pm 15.5\end{array}$ & $\begin{array}{c}0.26 \\
0.26 \pm 0.01 \\
0.25 \pm 0.01 \\
\end{array}$ & $\begin{array}{c}0.73 \\
0.72 \pm 0.04 \\
0.54 \pm 0.11\end{array}$ \\
\hline $\begin{array}{c}\mathrm{FTO} / \mathrm{b}-\mathrm{TiO}_{2} / \mathrm{m}^{-\mathrm{TiO}_{2}} / \text { perovskite} / 5 / \mathrm{Au} \\
\text { Champion } \\
\text { Forward } \\
\text { Backward }\end{array}$ & 17.50 & $\begin{array}{c}1.14 \\
1.02 \pm 0.56 \\
0.59 \pm 0.06 \\
\end{array}$ & $\begin{array}{c}4.55 \\
4.09 \pm 2.25 \\
2.38 \pm 0.24 \\
\end{array}$ & $\begin{array}{c}464.3 \\
472.5 \pm 14.6 \\
475.2 \pm 9.1 \\
\end{array}$ & $\begin{array}{c}0.25 \\
0.27 \pm 0.16 \\
0.22 \pm 0.01\end{array}$ & $\begin{array}{c}0.60 \\
0.57 \pm 0.09 \\
0.28 \pm 0.04\end{array}$ \\
\hline $\begin{array}{c}\mathrm{FTO} / \mathrm{b}-\mathrm{TiO}_{2} / \mathrm{m}-\mathrm{TiO}_{2} / \text { perovskite } / 5 / \mathrm{Au} \\
\text { Champion } \\
\text { Forward } \\
\text { Backward }\end{array}$ & 35.00 & $\begin{array}{c}1.19 \\
1.05 \pm 0.47 \\
0.71 \pm 0.25\end{array}$ & $\begin{array}{c}4.74 \\
4.20 \pm 1.87 \\
2.85 \pm 0.98\end{array}$ & $\begin{array}{c}500.9 \\
487.0 \pm 8.6 \\
482.6 \pm 10.5\end{array}$ & $\begin{array}{c}0.25 \\
0.24 \pm 0.01 \\
0.23 \pm 0.00\end{array}$ & $\begin{array}{c}0.67 \\
0.57 \pm 0.29 \\
0.37 \pm 0.14\end{array}$ \\
\hline $\begin{array}{c}\mathrm{FTO} / \mathrm{b}-\mathrm{TiO}_{2} / \mathrm{m}^{-\mathrm{TiO}_{2}} / \text { perovskite} / 6 / \mathrm{Au} \\
\text { Champion } \\
\text { Forward } \\
\text { Backward }\end{array}$ & 8.75 & $\begin{array}{c}3.36 \\
3.35 \pm 0.10 \\
2.87 \pm 0.14\end{array}$ & $\begin{array}{c}13.43 \\
13.40 \pm 0.41 \\
11.48 \pm 0.58\end{array}$ & $\begin{array}{c}379.8 \\
382.2 \pm 16.3 \\
349.3 \pm 0.92\end{array}$ & $\begin{array}{c}0.26 \\
0.26 \pm 0.00 \\
0.21 \pm 0.00\end{array}$ & $\begin{array}{c}1.36 \\
1.35 \pm 0.01 \\
0.85 \pm 0.03\end{array}$ \\
\hline $\begin{array}{c}\mathrm{FTO} / \mathrm{b}-\mathrm{TiO}_{2} / \mathrm{m}^{-\mathrm{TiO}_{2}} / \text { perovskite} / 6 / \mathrm{Au} \\
\text { Champion } \\
\text { Forward } \\
\text { Backward }\end{array}$ & 17.50 & $\begin{array}{c}2.95 \\
2.55 \pm 0.46 \\
2.36 \pm 0.10\end{array}$ & $\begin{array}{c}11.80 \\
10.22 \pm 1.83 \\
9.43 \pm 0.39\end{array}$ & $\begin{array}{c}628.8 \\
661.8 \pm 33.86 \\
714.7 \pm 27.63\end{array}$ & $\begin{array}{c}0.25 \\
0.25 \pm 0.00 \\
0.26 \pm 0.01\end{array}$ & $\begin{array}{c}1.88 \\
1.72 \pm 0.27 \\
1.79 \pm 0.11\end{array}$ \\
\hline
\end{tabular}


Table 4. Cont.

\begin{tabular}{|c|c|c|c|c|c|c|}
\hline Device Structure & $\begin{array}{c}\text { V }_{\text {Li-TFSI }} \\
{[\mu \mathrm{L}]}\end{array}$ & $\begin{array}{c}\mathbf{I}_{\mathrm{sc}} \\
{[\mathrm{mA}]}\end{array}$ & $\begin{array}{c}\mathrm{J}_{\mathrm{sc}} \\
{\left[\mathrm{mA} / \mathrm{cm}^{2}\right]}\end{array}$ & $\begin{array}{c}\mathrm{V}_{\mathrm{oc}} \\
{[\mathrm{mV}]}\end{array}$ & $\begin{array}{l}\text { FF } \\
{[-]}\end{array}$ & $\begin{array}{c}\text { PCE } \\
{[\%]}\end{array}$ \\
\hline \multicolumn{7}{|c|}{$\mathrm{FTO} / \mathrm{b}-\mathrm{TiO}_{2} / \mathrm{m}-\mathrm{TiO}_{2} /$ perovskite/6/Au } \\
\hline Champion & & 4.26 & 17.03 & 757.5 & 0.23 & 2.94 \\
\hline Forward & 35.00 & $4.25 \pm 0.04$ & $17.01 \pm 0.16$ & $754.7 \pm 3.37$ & $0.22 \pm 0.01$ & $2.91 \pm 0.04$ \\
\hline Backward & & $4.32 \pm 0.21$ & $17.26 \pm 0.84$ & $752.0 \pm 12.09$ & $0.21 \pm 0.00$ & $2.74 \pm 0.18$ \\
\hline
\end{tabular}

$\mathbf{V}_{\text {Li-TFSI }}$-volume of additive of solution Li-TFSI; - without HTM; Champion-device with the best PCE parameters.

Taking into account the I-V characteristics registered in a forward and backward scan, the hysteresis, which often appears in PCSs, was seen [29]. Hysteresis had unfavorable impacts on photovoltaic performance of PSCs $[30,31]$. The PCE was lower in the range of $0.07-0.72 \%$ than that of the forward scan, which is a rather significant value considering the low value of PCE exhibited by fabricated devices. The obtained results showed the effect of both structure of carbazole substituent and dopant concentration on PV parameters. The application of a molecule with 9-ethylcarbazolyl units (5) increased $V_{\mathrm{oc}}$ but reduced the $\mathrm{J}_{\mathrm{sc}}$ and finally resulted in lower PCE compared to the reference device. Higher PCE values were obtained for the cells with $\mathbf{4}$ and $\mathbf{6}$ compounds in all doping concentrations. However, the amount of Li-TFSI, which prevents the highest conversion efficiency, was different for device with $\mathbf{4}$ and $\mathbf{6}$. The optimal $\mathrm{V}_{\mathrm{Li} \text {-TFSI }}$ for PSC with oxetane bearing naphthalene (4) and triphenylamine structures (6) was 17.50 and $35.00 \mu \mathrm{L}$, respectively. Such doping concentrations raise the PCE mainly due to an increase in $\mathrm{J}_{\mathrm{sc}}$. The highest $\mathrm{V}_{\mathrm{oc}}$ above $600 \mathrm{mV}$ was observed for the device with compound 6 relative to the others, which can be explained by their differences in HOMO energy levels [10]. Moreover, cells based on oxetane substituted with 4-(diphenylamino)phenyl moieties (6) showed the highest PCE of $2.94 \%$.

\section{Conclusions}

The carbazole functionalized oxetanes substituted with the 1-naphthyl, 9-ethylcarbazolyl and 4-(diphenylamino)phenyl units were synthesized and investigated. Considering the impact of carbazole substituent structures it was found that:

- molecules with 9-ethylcarbazol-3-yl (5) and 4-(diphenylamino)phenyl (6) substituents were obtained as amorphous materials. The presence of 9-ethylcarbazolyl (5) units raised the glass transition temperature by about $20^{\circ} \mathrm{C}$ when compared with the others;

- 1-naphthyl (4) units increased PL quantum yields both in solution and in film (87\% in solutions and $9 \%$ in film), hypsochromically shifted $\lambda_{\mathrm{em}}$, lowered the HOMO energy level to $-5.86 \mathrm{eV}$, broadened the energy gap to $3.45 \mathrm{eV}$, and raised $\mathrm{J}_{\mathrm{sc}}$ and $\mathrm{V}_{\mathrm{oc}}$ of the device compared to the reference cell,

- 9-ethylcarbazolyl (5) moieties reduced the PL quantum yield, narrowed the bandgap to $3.25 \mathrm{eV}$ and significantly reduced $\mathrm{J}_{\mathrm{sc}}$ which negatively affected the PCE of the device,

- the 4-(diphenylamino)phenyl (6) substituents raised the HOMO energy level to $-5.48 \mathrm{eV}$, which has a beneficial impact on $\mathrm{V}_{\text {oc }}$ of device.

It can be concluded that utilization of oxetane derivatives with 4-(diphenylamino) phenyl units in perovskite cell led to a 2.5 times increase in PCE values in relation to the reference device, likely due to its HOMO energy level best matching to perovskite. Further, chemical modification of this compound seems to be promising for improving its properties toward efficient hole transporting materials.

Supplementary Materials: The following are available online at https:/ /www.mdpi.com/article/10 $.3390 / \mathrm{ma14195569/s1}$, Figure Figure S1. Mass spectra, ${ }^{1} \mathrm{H}$ NMR and ${ }^{13} \mathrm{C}$ NMR spectra of compounds 4, 5 and 6, Figure S2. TGA curves of compounds: (a) 4, (b) 5, (c) 6. Figure S3. DSC curves of the compounds: (a) 5, (b) 6. Figure S4. Additional scans for compounds 4, 5 and 6. Figure S5. Imposed UV-Vis and excitation spectra, respectively (dotted line) as well as PL spectra (solid line) of 
compounds $\left(4,5\right.$ and 6) in various solvents: (a) chloroform $\left(\mathrm{CHCl}_{3}\right)$, (b) dichloromethane $\left(\mathrm{CH}_{2} \mathrm{Cl}_{2}\right)$, (c) methanol $\left(\mathrm{CH}_{3} \mathrm{OH}\right)$, d) acetonitrile $\left(\mathrm{CH}_{3} \mathrm{CN}\right)$. Figure S6. Imposed UV-Vis and excitation spectra, respectively (dotted line) as well as PL spectra (solid line) in various solvents for compound: (a) 4, (b) 6. Figure S6a. Calculated electronic absorption spectra of compounds 4, 5 and 6 in selected solvents. Figure S7. 3D spectra for the analyzed compounds $(4,5,6)$ in the excitation range from 230 to $400 \mathrm{~nm}$ and the collected emissions in the range from 300 to $550 \mathrm{~nm}$ in three solvents: chloroform $\left(\mathrm{CHCl}_{3}\right)$, dichloromethane $\left(\mathrm{CH}_{2} \mathrm{Cl}_{2}\right)$ and acetonitryl $\left(\mathrm{CH}_{3} \mathrm{CN}\right)$. Figure S8. The excitation (dotted line) PL spectra (solid line) for compounds in (a) powder, (b) film. Figure S9. Experimental and calculated IR spectra of 4,5 and 6 compounds. Figure S10. The optimized geometries of compounds 4, 5 and 6. Figure S10a. Optimized geometries of ground (green), S1 (red) and T1 (blue) states of compounds 4, 5 and 6. (Hydrogen atoms were omitted for clarity). Figure S11. DOS spectra of the investigated compounds. Figure S12. The photoluminescence (PL) properties of tested compounds (10 $\mu \mathrm{M}$ concentration) in a binary mixture of $\mathrm{CH}_{3} \mathrm{CN} / \mathrm{H}_{2} \mathrm{O}$ with an increasing water content $(\mathrm{fw}=0$, $10,20,30,40,50,60,70,80,90 \%, v / v$ ) at different excitation wavelengths (ex.: 300, 320, 340, $360 \mathrm{~nm}$ ) for: (a) 4, (b) 5, (c) 6. Figure S13. I-V characteristics of the champion devices. Table S1. Number of electrons during oxidation process. Table S2. Composition of the selected molecular orbitals. Table S3. Energy differences $[\mathrm{nm}]$ between ground and $\mathrm{S}_{1}, \mathrm{~T}_{1}$ excited states calculated in $\mathrm{CH}_{2} \mathrm{Cl}_{2}$ solvent (the maxima of emission wavelength are given in parenthesis) and calculated dipole moments. Table S4. The calculated electronic transitions corresponding to excitation wavelength in $\mathrm{CH}_{2} \mathrm{Cl}_{2}$ solution.

Author Contributions: M.K.-investigation, writing-original draft; D.T.-synthesis and characterization; R.B.-investigation of properties; N.S.S.—investigation of properties; G.K.-synthesis and characterization; S.G.—writing-original draft, investigation, visualization, review \& editing; S.K., M.V., A.K.P., P.G.—investigation, writing-original draft; J.G.M.-theoretical calculations, writing —original draft; E.S.-B.—writing—original draft, visualization, review \& editing, supervision. All authors have read and agreed to the published version of the manuscript.

Funding: This work was supported by the National Science Centre of Poland Grant: No. 2018/31/B/ ST8/03294. The investigations of synthesis were funded by the grant from Kaunas University of Technology and Vytautas Magnus University. GK is obliged for stipend for Lithuanian Academy of Sciences. The research was co-financed by the funds granted under the Research Excellence Initiative of the University of Silesia in Katowice. The GAUSSIAN-09 calculations were carried out in the Wrocław Centre for Networking and Supercomputing, WCSS, Wrocław, Poland, http: / / www.wcss.wroc.pl (accessed on 2 September 2021) (grant No. 18).

Institutional Review Board Statement: Not applicable.

Informed Consent Statement: Not applicable.

Data Availability Statement: The data presented in this study are available on request from the corresponding author.

Conflicts of Interest: The authors declare that they have no known competing financial interests or personal relationships that could have appeared to influence the work reported in this paper.

\section{References}

1. Rao, M.K.; Sangeetha, D.N.; Selvakumar, M.; Sudhakar, Y.N.; Mahesha, M.G. Review on persistent challenges of perovskite solar cells' stability Sol. Energy 2021, 218, 469-491.

2. Vidal, R.; Alberola-Borràs, J.-A.; Sánchez-Pantoja, N.; Mora-Seró, I. Comparison of Perovskite Solar Cells with other Photovoltaics Technologies from the Point of View of Life Cycle Assessment Adv. Energy Sustain. Res. 2021, 2, 2000088. [CrossRef]

3. Zhang, L.; Zhou, X.; Liu, C.; Wang, X.; Xu, B. A Review on Solution-Processable Dopant-Free Small Molecules as Hole-Transporting Materials for Efficient Perovskite Solar Cells. Small Methods 2020, 4, 2000254. [CrossRef]

4. Bakr, Z.H.; Wali, Q.; Fakharuddin, A.; Schmidt-Mende, L.; Brown, T.M.; Jose, R. Advances in hole transport materials engineering for stable and efficient perovskite solar cells. Nano Energy 2017, 34, 305. [CrossRef]

5. Kwon, H.; Lim, J.W.; Han, J.; Quan, L.N.; Kim, D.; Shin, E.S.; Kim, E.; Kim, D.W.; Noh, Y.Y.; Chunh, I.; et al. Towards efficient and stable perovskite solar cells employing non-hygroscopic F4-TCNQ doped TFB as the hole-transporting material. Nanoscale 2019, 11, 19586-19594. [CrossRef] [PubMed]

6. Vivo, P.; Salunke, J.K.; Priimagi, A. Hole-transporting materials for printable perovskite solar cells Materials. Basel 2017, 10, 1-45.

7. Liu, F.; Li, Q.; Li, Z. Hole-Transporting Materials for Perovskite Solar Cells Asian. J. Org. Chem. 2018, 7, $2182-2200$.

8. Calio, L.; Kazim, S.; Gratzel, M.; Ahmad, S. Hole-Transport Materials for Perovskite Solar Cells. Angew. Chem. Int. Ed. 2016, 55, 14522-14545. [CrossRef] [PubMed] 
9. Mesquita, I.; Andrade, L.; Mendes, A. Perovskite solar cells: Materials, configurations and stability. Renew. Sustain. Energy Rev. 2018, 82, 2471-2489. [CrossRef]

10. Shen Ch Wu, Y.; Zhang, H.; Li, E.; Zhang, W.; Xu, X.; Wu, W.; Tian, H.; Zhu, W.-H. Semi-Locked Tetrathienylethene as a Building Block for Hole-Transporting Materials: Toward Efficient and Stable Perovskite Solar Cells. Angew. Chem. Int. Ed. 2019, 131, 3824-3829.

11. Xu, L.; Huang, P.; Zhang, J.; Jia, X.; Ma, Z.; Sun, Y.; Zhou, Y.; Yuan, N.-Y.; Ding, J.-N. N,N-Di-para-methylthiophenylamineSubstituted (2-Ethylhexyl)-9H-Carbazole: A Simple, Dopant-Free Hole-Transporting Material for Planar Perovskite Solar Cells. J. Phys. Chem. C 2017, 121, 21821-21826. [CrossRef]

12. Zhang, J.; Xu, L.J.; Zhou, Y.; Zhu, Y.Y.; Yuan, N.Y.; Ding, J.N.; Zhang, Z.G.; Li, Y.F. A simple and dopant-free hole-transporting material based on (2-ethylhexyl)-9H-carbazole for efficient planar perovskite solar cells. J. Mater. Chem. C 2017, 5, 12752-12757. [CrossRef]

13. Zhang, J.; Xu, B.; Johansson, M.B.; Vlachopoulos, N.; Boshloo, G.; Sun, L.; Johansson, E.M.J.; Hagfeld, A. Strategy to Boost the Efficiency of Mixed-Ion Perovskite Solar Cells: Changing Geometry of the Hole Transporting Material. ACS Nano 2016, 10, 6816-6825. [CrossRef]

14. Tucker, S.H. Iodination in the Carbazole Series. J. Chem. Soc. 1926, 1, 548.

15. Blazevicius, D.; Krucaite, G.; Tavgeniene, D.; Griniene, R. New structure host material for phosphorescent OLED devices. Mol. Cryst. Liq. Cryst. 2021, 716, 69-75. [CrossRef]

16. Slodek, A.; Zych, D.; Golba, S.; Zimosz, S.; Gnida, P.; Schab-Balcerzak, E. Dyes based on the D/A-acetylene linker-phenothiazine system for developing efficient dye-sensitized solar cells. J. Mater. Chem. C 2019, 7, 5830-5840. [CrossRef]

17. Pluczyk, S.; Zassowski, P.; Quinton, C.; Audebert, P.; Alain-Rizzo, V.; Lapkowski, M. Unusual Electrochemical Properties of the Electropolymerized Thin Layer Based on a s-Tetrazine-Triphenylamine Monomer. J. Phys. Chem. C 2016, 120, 4382-4391. [CrossRef]

18. Karon, K.; Lapkowski, M. Carbazole electrochemistry: A short review. J. Solid State Electrochem. 2015, 19, 2601-2610. [CrossRef]

19. Kula, S.; Pajakk, A.; Szlapa-Kula, A.; Mieszczanin, A.; Gnida, P.; Lipiński, M.; Schab-Balcerzak, E. 9,9'-bifluorenylidene derivatives as novel hole-transporting materials for potential photovoltaic applications. Dye. Pigm. 2020, 174, 108031. [CrossRef]

20. Huang, C.; Fu, W.; Li, C.; Zhang, Z.; Qiu, W.; Shi, M.; Heremans, P.; Jen AK, Y.; Chen, H.J. Dopant-Free Hole-Transporting Material with a $\mathrm{C}_{3 \mathrm{~h}}$ Symmetrical Truxene Core for Highly Efficient Perovskite Solar Cells. Am. Chem. Soc. 2016, 138, 2528-2531. [CrossRef]

21. Petrus, M.L.; Music, A.; Closs, A.C.; Bijleveld, J.C.; Sirtl, M.T.; Hu, Y.; Dingemans, T.J.; Bein, T.; Docampo, P. Design rules for the preparation of low-cost hole transporting materials for perovskite solar cells with moisture barrier properties. J. Mater. Chem. A 2017, 5, 25200-25210. [CrossRef]

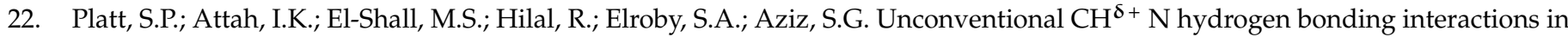
the stepwise solvation of the naphthalene radical cation by hydrogen cyanide and acetonitrile molecules. Phys. Chem. Chem. Phys. 2016, 18, 2580-2590. [CrossRef] [PubMed]

23. Mason, K.A.; Pearcy, A.C.; Lao, K.U.; Christensen, Z.A.; El-Shall, M.S. Non-covalent interactions of hydrogen cyanide and acetonitrile with the quinoline radical cation via ionic hydrogen bonding. Chem. Phys. Lett. 2020, 754, 1377442. [CrossRef]

24. Korzec, M.; Senkała, S.; Rzycka-Korzec, R.; Kotowicz, S.; Schab-Balcerzak, E.; Polański, J. A highly selective and sensitive sensor with imine and phenyl-ethynylphenylunits for the visual and fluorescent detection of copper in water. J. Photochem. Photobiol. A Chem. 2019, 382, 111893. [CrossRef]

25. Song, Q.H.; Wang, H.B.; Tang, W.J.; Guo, Q.X.; Yu, S.Q. Model studies of the (6-4) photoproduct photoreactivation: Efficient photosensitized splitting of thymine oxetane units by covalently linked tryptophan in high polarity solvents. Org. Biomol. Chem. 2006, 4, 291-298. [CrossRef]

26. Wang, H.; Zhao, E.; Lam, J.W.Y.; Tang, B.Z. AIE luminogens: Emission brightened by aggregation. Mater. Today 2015, 18, 365-377. [CrossRef]

27. Alam, P.; Climent, C.; Alemany, P.; Laskar, I.R. Aggregation-induced emission of transition metal compounds: Design, mechanistic insights, and applications. J. Photochem. Photobiol. C Photochem. Rev. 2019, 41, 100317. [CrossRef]

28. Korzec, M.; Kotowicz, S.; Rzycka-Korzec, R.; Schab-Balcerzak, E.; Małecki, J.G.; Czichy, M.; Łapkowski, M. Novel $\beta$-ketoenamines versus azomethines for organic electronics: Characterization of optical and electrochemical properties supported by theoretical studies. J. Mater. Sci. 2020, 55, 3812-3832. [CrossRef]

29. Huang, J.; Gao, C.; Zhang, D.; Tian, Q.; Zhang, F.; Liu, S.h.F. Influence of Film Quality on Power Conversion Efficiency in Perovskite Solar Cells. Coatings 2019, 9, 622. [CrossRef]

30. Liu, P.; Wang, W.; Liu, S.; Yang, H.; Shao, Z. Fundamental Understanding of Photocurrent Hysteresis in Perovskite Solar Cells. Adv. Energy Mater. 2019, 9, 1803017. [CrossRef]

31. Kang, D.H.; Park, N.G. On the Current-Voltage Hysteresis in Perovskite Solar Cells: Dependence on Perovskite Composition and Methods to Remove Hysteresis. Adv. Mater. 2019, 31, 1805214. [CrossRef] [PubMed] 